\title{
MOTIVASI BEKERJA DI VIHĀRA PADA WANITA DEWASA AWAL
}

(Studi Kasus di Vihāra Tanah Putih Semarang)

\author{
Sukodoyo \\ sukodoyosyailendra@gmail.com
}

\begin{abstract}
ABSTRAK
Penelitian ini dilatarbelakangi sulitnya wanita dewasa awal mendapatkan pekerjaan yang yang sesuai. Penelitian ini bertujuan untuk mengetahui motivasi wanita dewasa awal untuk bekerja di vihāra. Penelitian ini merupakan jenis penelitian kualitatif dengan pendekatan fenomenologis. Subjek penelitian yaitu wanita dewasa awal yang berusia 19-22 tahun, lulusan Sekolah Menengah Atas atau Sekolah Menengah Kejuruan yang bekerja di Vihāra Tanah Putih Semarang. Pengumpulan data dilakukan dengan wawancara dan observasi, selanjutnya data dianalisis secara kualitatif dengan langkah-langkah: reduksi data, penyajian data, dan menarik kesimpulan. Keabsahan data dilakukan dengan ketekunan, triangulasi, diskusi teman sejawat, dan perpanjangan keikutsertaan. Hasil penelitian menunjukkan bahwa wanita dewasa awal mau bekerja di vihāra karena didasari adanya keyakinan ( saddha) yang kuat tentang hukum sebab akibat (hukum kamma). Wanita dewasa awal ketika bekerja di vihāra mempunyai keyakinan bekerja di vihāra sambil berbuat baik. Selain itu, termotivasi adanya lowongan pekerjaan yang ada di vihāra, mencari modal, dan mencari pengalaman.
\end{abstract}

Kata Kunci: motivasi, bekerja, wanita dewasa awal, vihāra

\section{ABSTRACT}

The research is inspired by the difficulty of the early adult women to get appropriate jobs. This research aims to know about motivation of the early adult women to work in the monastery.

This research is a qualitative research with a phenomenological approach. The research subjects are early adult women aged 19-22 years, graduate from senior high school/vocational school that work in Tanah Putih Monastery, Semarang. The data was collected through interview and observation, and then the data was analyzed qualitatively with these steps: data reduction, data presentation, and conclusion. The validity of the data was done with persistence, triangulation, peer discussions, and extensive of participation.

The results showed that early adult women worked in the monastery because it is based on the strong belief of the law of cause and effect (law of kamma). Early adult women while working at the monastery have had the belief that working in a monastery with doing kindness. In addition, they were motivated by the job availability that existed in the monastery, seeking capital, and getting experience.

Key words: motivation, work, early adult women, monastery

\section{PENDAHULUAN}

Pada era globalisasi wanita bekerja menjadi suatu hal yang wajar. Kedudukan wanita dan laki-laki sebagai makhluk sosial mempunyai hak yang sama dalam hidup dan menentukan masa depan merupakan salah satu faktor wanita bekerja. Wanita dewasa awal bekerja merupakan bagian dari tugas perkembangan yang berkaitan dengan pekerjaan. Tugas perkembangan dan tuntutan untuk meningkatkan sumber daya manusia yang berguna di masyarakat merupakan kebutuhan wanita untuk bekerja.

Kondisi lain yang dianggap pokok adalah memilih bidang yang cocok dengan bakat, minat, dan faktor psikologis lainnya secara hakiki sulit untuk dipungkiri agar kesehatan mental dan fisiknya sebagai orang dewasa dapat terjaga (Hurlock, 1980: p. 279). Hal tersebut menyebabkan kebingungan pada banyak lulusan Sekolah Menengah Atas (SMA) atau Sekolah Menengah Kejuruan (SMK) yang ingin melanjutkan studi dan tidak mampu secara ekonomi. Lowongan pekerjaan yang minim dan penggangguran yang semakin bertambah mengakibatkan wanita dewasa awal sulit mendapatkan pekerjaan. Tuntutan kompetensi yang tinggi bagi lulusan SMA/SMK dalam dunia kerja berdampak pada pilihan pekerjaan. 
Keinginan yang diharapkan dan tidak tersedia dalam dunia kerja mengakibatkan wanita dewasa awal bekerja seadanya. Zannatos dan Zafiris (1994), wanita sebagai salah satu sumber daya di pasar tenaga kerja terutama di Indonesia mempunyai kontribusi yang besar dalam arti bahwa jumlah wanita yang menawarkan dirinya untuk bekerja cukup besar. Wanita dewasa awal atau dini dimulai dari umur 18 sampai kira-kira umur 40 tahun (Hurlock, 1980: p. 246). Faktor ekspektasi dan kebutuhan menjadikan salah satu alasan wanita dewasa awal harus bekerja.

Bekerja (Kamus Besar Bahasa Indnesia, 2008: p. 704), adalah melakukan suatu pekerjaan. Pekerjaan tersebut lebih identik dengan mencari nafkah atau mata pencaharian. Hasil wawancara (Jumat, 2 November 2011) dengan salah satu wanita dewasa awal mantan pekerja vihāra Tanah Putih Semarang. Sewaktu lulus SMA dan berkeinginan kuliah tetapi tidak memiliki biaya. Subjek berasal dari keluarga petani musiman dari salah satu kabupaten di Jawa Tengah. Mendengar dari salah satu tetangga tentang infornasi lowongan pekerjaan sebagai tenaga administrasi, subjek mendaftar untuk bekerja di vihāra.

Latar belakang tidak memiliki pekerjaan dan mengganggur membuat subjek mau bekerja di vihāra. Sebelum bekerja subjek sudah diberitahu oleh tetangga bahwa bekerja di vihāra gaji sedikit tetapi dapat berbuat baik. Selain hal tersebut subjek juga di dorong pengalaman SMA tinggal di asrama vihāra. Oleh karena itu subjek memutuskan untuk bekerja di vihāra dan mencari modal serta pengalaman dalam bekerja. Pada saat interview subjek diberitahu kondisi pekerjaan, gaji, dan prasarana, serta sarana di vihāra yang sederhana.

Pada kasus di atas, sebelum bekerja di vihāra, subjek berkeinginan melanjutkan studi dan orang tua tidak mampu membiayai. Keinginan subjek untuk melanjutkan studi yang belum tercapai membuat subjek bekerja. Dalam bekerja subjek juga berkeinginan untuk dapat memenuhi kebutuhan pribadi dan membantu keluarga. Selama bekerja di vihāra, subjek dari pagi mempersiapkan sarapan untuk temanteman subjek dan makan pagi untuk samanera. Subjek kemudian bekerja dengan mengurusi administrasi yayasan, vihāra, rumah abu, dan perpustakaan. Selama subjek bekerja di vihāra, setiap ada orang yang mendaftar dan bekerja di administrasi vihāra hanya bertahan 1-3 bulan.

Keinginan subjek untuk melanjutkan studi berhasil. Hal tersebut diawali dengan subjek bekerja di vihāra dan peneliti mengenalkan subjek dengan yayasan anak asuh yang mau membantu biaya studi dengan melihat prestasi, pengabdian, dan kondisi subjek. Peneliti mengenal subjek karena bersama-sama dalam kepengurusan organisasi pemuda di Jawa Tengah dan merasa kasihan sehingga mencarikan informasi untuk dapat membantu studi subjek. Bantuan biaya studi tiap semester dan sisa tabungan yang didapat membuat subjek dapat melanjutkan studi. Subjek melakukan aktivitas kuliah pada pukul 17.30-20.30 WIB setiap Senin-Jumat di salah satu Sekolah Tinggi Ilmu Komputer dan Akuntansi di Semarang. Meskipun tidak memiliki motor atau alat transportasi sendiri, subjek memberanikan diri untuk naik angkot sewaktu pulang kuliah.

Berdasarkan wawancara (Kamis, 3 November 2011, di Kampus subjek), dapat dikatakan bahwa subjek memiliki motivasi yang kuat untuk bekerja dan mengubah kondisi hidup menjadi lebih baik walaupun pada awalnya dilatarbelakangi karena tidak memiliki pekerjaan. Subjek hanya mampu bertahan bekerja di vihāra selama 19 bulan dikarenakan sakit dan harus operasi pada usus 12 jari yang tersumbat. Hal tersebut membuat subjek keluar dari bekerja di vihāra dan berfokus pada kesehatan serta kuliah.

Selain pada beberapa hal di atas, latar belakang perlu ditelitinya motivasi bekerja pada wanita dewasa awal juga dipengaruhi fenomena dan pengalaman peneliti saat membantu vihāra. Fenomena tersebut terletak pada wanita dewasa awal yang bekerja di vihāra. Para wanita tersebut hanya bertahan antara 1-3 bulan. Berdasarkan pada wawancara dengan subjek di atas dan pengalaman peneliti pada vihāra tersebut selama tahun 2011 di sekretrariat vihāra sudah mengalami pergantian sebanyak 3 kali, sementara di perpustakaan dan rumah abu 1 kali. Para wanita dewasa awal keluar dari bekerja di vihāra dan lebih khusus motivasi bekerja mempunyai pengaruh pada fenomena tersebut.

Motivasi kerja adalah hal yang menyebabkan, menyalurkan dan mendukung perilaku manusia, supaya mau bekerja giat dan antusias mencapai hasil yang optimal (Prabu, 2005). Dalam kaitan dengan motivasi bekerja 
maka motivasi dapat diartikan sebagai pendorong wanita dewasa awal untuk bekerja. Motivasi merupakan dorongan, keinginan, sehingga seseorang melakukan suatu kegiatan atau pekerjaan dengan memberikan yang terbaik bagi dirinya, baik waktu maupun tenaga, demi tercapai tujuan yang diinginkan (Anoraga dan Suyati, 1995: p. 115).

Bekerja pada masa dewasa menandakan dimulainya peran dan tanggung jawab baru bagi individu. Peran karir berbeda dengan peran yang mungkin dimiliki individu sebagai seorang pekerja sementara atau paruh waktu saat remaja (Santrock, 2002: p. 96). Menurut Teori Kebutuhan Maslow, bekerja dimaksudkan sebagai usaha yang dilakukan individu untuk mengisi kekurangan dalam hidupnya, jadi individu mengeluarkan usaha untuk memenuhi kebutuhan-kebutuhannya (Jewwel dan Siegall, 1998: p. 336). Greenberg \& Robert (2003: p. 190), motivasi bekerja adalah seperangkat proses yang membangkitkan, mengarahkan, dan mempertahankan perilaku manusia untuk mencapai suatu tujuan.

Dewasa awal merupakan awal dari suatu tahap baru dalam tahapan perkembangan kehidupan. Individu telah menjalani masa remaja dan kini akan memasuki tahap pencapaian kedewasaan dengan segala tantangan yang lebih beragam bentuknya (Turner \& Helms, 1995). Dewasa awal menurut Hurlock (1980: p. 246) merupakan masa dewasa awal. Istilah dewasa awal dan dewasa awal merupakan istilah yang sama hanya berbeda rentang usia yang disebabkan perbedaan dari para tokoh penelitinya.

Terdapat berbagai pendapat mengenai batasan usia dewasa awal. Hurlock, (1980: p. 246) memberikan batasan masa dewasa awal antara 18 sampai umur 40 tahun. Turner dan Helms (1995) menyatakan bahwa usia 20 sampai 30 tahunlah batasan usia dewasa awal, dan yang terakhir adalah Levinson (Turner dan Helms, 1995) yang menyebutkan bahwa batasan usia dewasa awal adalah 20 sampai 40 tahun.

Vihāra merupakan tempat tinggal para bhikkhu (Panjika, 2004: p. 379). Istilah bhikkhu dalam kamus Pāli-English (Davids, 1992: p. 504) berasal dari kata bhiks yang berarti peminta sedekah. Terjemahan tersebut tidak mencerminkan pengertian yang sebenarnya karena bhikkhu tidak meminta tetapi menerima apa yang dipersembahkan kepadanya. Menurut
Widya (2005: p. 21), bhikkhu (bhikshu dalam bahasa Sansekerta) adalah umat Buddha pria yang hidup melepaskan diri dari keduniawian (berumah tangga) dan mengikuti cara hidup sebagai pertapa menurut peraturan (vinaya). Sedangkan tempat berteduh bagi bhikkhu atau samanera (calon bhikkhu) disebut dengan kuti (Panjika, 2004: p. 358). Vihāra merupakan tempat tinggal rohaniawan agama Buddha. Dalam perkembangannya vihāra identik dengan tempat ibadah umat beragama Buddha.

Dari definisi di atas, dapat disimpulkan bahwa motivasi wanita dewasa awal bekerja di vihāra adalah dorongan wanita yang berusia 1840 tahun yang mengarahkan tingkah laku untuk mencapai tujuan peran dan tanggung jawabnya sebagai individu di tempat ibadah umat Buddha.

\section{Motivasi Bekerja dalam Agama Buddha}

Motivasi bekerja merupakan dorongan untuk menuju perubahan kearah yang lebih baik. Motivasi dapat terjadi apabila terdapat unsur keyakinan (saddhā). Keyakinan merupakan suatu sikap batin yang mendorong seseorang untuk melakukan tindakan sesuai dengan apa yang diyakini. Keyakinan terhadap sesuatu yang benar akan menghasilkan perbuatan yang benar, demikian sebaliknya keyakinan terhadap sesuatu yang salah akan menghasilkan perbuatan yang salah pula.

Buddha menjelaskan dalam Samyutta Nikāya (Bodhi, 2000: p. 267), keyakinan merupakan benih yang digunakan untuk mencapai kebahagiaan. Saddh $\bar{a}$ merupakan hal yang paling dasar yang harus dimiliki oleh para perumah tangga untuk mencapai kebahagiaan. Buddha menjelaskan kepada Bodhi dalam Bodhirajakumara Sutta, Majjhima Nikāya (Horner, 2002: p. 282), bahwa saddhā sebagai tingkatan pertama dalam faktor usaha untuk mencapai keberhasilan. Landasan awal untuk memperoleh kesuksesan adalah dengan memiliki saddhà serta didukung dengan adanya usaha keras.

Saddh $\bar{a}$ merupakan salah satu yang mendukung umat Buddha untuk melakukan perbuatan baik. Perbuatan yang menyebabkan keberhasilan merupakan rangkaian proses sebab akibat dan disebut sebagai hukum kamma. Penjelasan tersebut disampaikan Buddha dalam Samyutta Nikāya (Bodhi, 2000: p. 328) yaitu, "Whatever sort of seed is sown, that is the sort of fruit one reaps: the doer of good reaps good; 
the doer of evil reaps evil. By you dear, has the seed been sown; thus you will experience the fruit". Seseorang yang melakukan perbuatan baik (kusala kamma) maka akan memetik hasil perbuatan baik (kamma vipaka) yang dilakukannya. Demikian pula dengan seseorang yang melakukan perbuatan tidak baik atau jahat (akusala kamma) maka akan memetik hasil dari perbuatan tidak baik atau jahat yang telah dilakukan. Timbunan perbuatan jahat menyebabkan seseorang dapat menderita. Sedangkan timbunan kebajikan dapat menghasilkan kekayaan. Proses tersebut merupakan akibat dari hukum kamma yang saling bergantungan antara perbuatan yang telah dilakukan dan hasil yang akan diperoleh.

Kebajikan atau memberi dengan tulus dalam Buddhisme identik dengan berdana. Dāna dalam Buddhime dikelompokkan dalam beberapa bagian. Masing-masing disesuaikan dengan kategori atau jenis dāna tersebut. Itivuttaka, Khuddaka-Nikāya (Masefield, 2001: p. 84) mengkategorikan dāna ke dalam dua bagian, secara materi (āmisa-dāna) dan dāna secara mental (dhamma-dāna). Secara materi dāna berupa makanan, pakaian, obat-obatan, dan tempat tinggal, sedangkan secara mental atau non-materi, seperti memberikan keterampilan, pelajaran, nasihat atau pengetahuan kebenaran. Buddhisme menekankan dāna harus dilakukan oleh setiap individu agar dalam kehidupan memperoleh kebahagiaan dan kesejahteraan. Hal tersebut merupakan salah satu dasar dan motivasi bagi umat Buddha untuk melakukan suatu pekerjaan.

Jadi bekerja dalam agama Buddha dapat diartikan sebagai segala bentuk dorongan atau usaha untuk mendapatkan perubahan yang lebih baik melalui keyakinan kuat dan perbuatan baik yang terwujud dalam dāna.

\section{Faktor-Faktor yang Mempengaruhi Motivasi Bekerja}

Faktor penyebab motivasi terdiri dari intrinsik dan ekstrinsik (Wade dan Carol, 2007: p. 144). Motivasi intrinsik merupakan keinginan untuk melakukan suatu aktivitas atau meraih pencapaian tertentu semata-mata demi kesenangan atau kepuasan yang didapat dari melakukan aktivitas tersebut. Sedangkan motivasi ekstrinsik merupakan keinginan untuk mengejar suatu tujuan yang diakibatkan oleh imbalan-imbalan eksternal. Sedangkan menurut Gomes (Azami, 2009), terdapat beberapa faktor yang menyebabkan motivasi untuk bekerja, yaitu: 1) faktor yang berasal dari dalam diri (intrinsik) terdiri dari a) kebutuhan, b) tujuantujuan, c) sikap, d) kemampuan; dan 2) faktorfaktor yang berasal dari luar diri (ekstrinsik) terdiri dari a) gaji atau upah, b) keamanan pekerjaan, c) kesesuaian sesame pekerja, d) pengawasan, e) pujian, dan f) pekerjaan itu sendiri.

Dalam Ańguttara Nikāya (Hare, 2001: p. 97) dijelaskan Buddha kepada para bhikkhu bahwa seseorang yang ingin berubah dari keadaan yang dialaminya, harus memiliki keyakinan (saddhā), moral yang baik (sīla), pengetahuan (bāhusacca), dan disiplin (viriyambha), serta bijaksana (pañ na), yaitu: " $a$ monk has faith, is virtuos, learned, energetic, and has insight". Keyakinan (saddhā) pada kemampuan yang dimiliki untuk berubah dan berjuang mencapai kesuksesan, serta tidak takut kepada resiko yang belum dan akan dialaminya. Moral (sīla) yang baik tercermin pada tingkah laku atau perbuatan yang dilakukan membuat individu dipercaya dan mendapat simpati serta mempermudah untuk bekerja sama dalam berbagai pekerjaan atau berusaha. Pengetahuan (bāhusacca) merupakan sarana untuk menjadi maju, kreatif, inovatif, serta mempermudah untuk menyelesaikan permasalahan. Disiplin (viriyambha) dalam bekerja berarti tekun, penuh semangat, dan pantang menyerah. Sikap tersebut membuat individu bertanggung jawab dan mendukung keberhasilan pada setiap pekerjaan yang dilakukan. Kebijaksanaan ( $p a \tilde{n} \tilde{n} a)$ merupakan sikap mengetahui tindakan yang akan dilakukan dan tidak merugikan. Kelima hal tersebut merupakan motivasi intrinsik yang harus dimiliki oleh setiap individu, sebab hal tersebut dapat membantu keberhasilan dan perubahan ke arah positif untuk berhasil dalam pekerjaan.

Selain faktor motivasi intrinsik dan ektrinsik, aspek motivasi sangat diperlukan dalam bekerja. Menurut Purwanto (2007: p. 72-102), aspek motivasi mempunyai peranan besar dalam keberhasilan seseorang dalam bekerja. Aspek motivasi tersebut, yaitu: 1) Menggerakkan merupakan aspek yang menunjukkan bahwa motivasi menimbulkan kekuatan pada individu atau mendorong untuk bertindak dengan cara-cara tertentu. Seperti kekuatan dalam hal ingatan, respon-respon afektif, dan kecenderungan mendapatkan kesenangan. 2) Mengarahkan merupakan aspek yang menunjukkan bahwa motivasi menjadi suatu orientasi tujuan tingkah laku diarahkan 
pada suatu tujuan bekerja. 3) Menopang merupakan aspek yang menunjukkan diperlukanya dukungan penguatan (reinforce) dari lingkungan sekitar selain kekuatan dari dalam individu sendiri. Aspek ini digunakan untuk menjaga tingkah laku bekerja.

Dari berbagai pendapat di atas dapat disimpulkan bahwa ada banyak faktor dan aspek yang dapat mempengaruhi motivasi seseorang untuk bekerja, baik dari dalam diri individu itu sendiri maupun dari luar individu. Faktor-faktor motivasi bekerja secara umum diantaranya kebutuhan, sikap, tujuan, kemampuan, gaji, keamanan pekerjaan, kondisi sosial, pengawasan, pujian, dan pekerja yang mengerakkan, mengarahkan dan menopang pekerjaan yang dilakukan. Sedangkan faktor motivasi bekerja dalam Buddhis adalah keyakinan, moral, pengetahuan, disiplin, dan kebjaksanaan.

\section{Ciri-Ciri Motivasi Tinggi}

Individu yang mempunyai motivasi tinggi menurut Weiner (1982: p. 203-215), mempunyai inisiatif yang berhubungan dengan dengan kerja, lebih tahan dalam menghadapi kegagalan, mempunyai intensitas tinggi, dan memiliki tingkat resiko sedang.

Dengan demikian dapat disimpulkan bahwa individu yang memiliki motivasi tinggi adalah individu yang memiliki inisiatif dan dorongan untuk mencapai tujuan dan masa depan, mempunyai intensitas tinggi, bersikap positif, percaya diri, bertanggung jawab dan disiplin dengan demikian lebih tahan dalam menghadapi kegagalan dan memiliki harapan untuk membuahkan hasil.

\section{Syarat Bekerja Sebagai Pegawai Administrasi di Vihāra}

Dalam bekerja di suatu vihāra bagi dewasa awal, terdapat kriteria yang di tentukan. Kriteria untuk dapat bekerja di vihāra dari masing-masing vihāra berbeda. Kriteria untuk dapat bekerja di vihāra tempat dilakukan penelitian adalah: 1) Pendidikan minimal SMA/SMK sederajat, 2) Menguasai komputer terutaman Microsoff Office Word dan Microsoff Office Excel, 3) Usia miniman 18 tahun, dan 4) Jujur dan bertanggunggjawab (Infomasi Lowongan Pekerjaan Vihāra Tanah Putih Semarang, Bulan Agustus 2011).

Kriteria tersebut merupakan syarat minimal individu dapat diterima dan bekerja di vihāra. Selain syarat minimal tersebut terdapat syarat tambahan yaitu beragama Buddha dan lolos test Wawancara. Dengan syarat-syarat tersebut individu diterima sebagai tenaga admistrasi di vihāra. Rata-rata dewasa awal yang bekerja di vihāra adalah wanita pada setiap tahunnya. Pada tahun 2009-2010 pernah terdapat tiga pria yang keluar masuk bekerja di vihāra, tetapi sebagian besar yang bekerja di bagian administrasi wanita dan pada tahun 2011 wanita yang mendaftar. Sehingga penelitian ini mengambil salah satu kriteria subjek wanita dewasa awal sebagai objek penelitian.

\section{Dinamika Motivasi Beke rja di Vihāra}

Wanita dewasa awal memiliki motivasi yang berbeda-beda untuk bekerja. Latar belakang pendidikan dan keluarga sangat mempengaruhi wanita mau bekerja. Kebutuhan bekerja pada pada wanita dewasa awal pada zaman modern sangat besar dan ingin bekerja sesuai keinginannya. Motivasi bekerja di vihāra berkaitan dengan motivasi internal dan eksternal dari wanita dewasa awal.

Motivasi internal untuk bekerja berkaitan dengan kebutuhan, tujuan-tujuan, sikap, dan kemampuan yang secara Buddhis di dukung dengan keyakinan, moral, pengetahuan, kedisiplinan, dan kebijaksanaan. Kebutuhan dan tujuan menjadi dasar dari dalam bagi seseorang untuk bekerja. Sedangkan sikap berkaitan dengan keyakinan, moral, kedisiplinan, dan kebijaksanaan. Kemampuan berkaitan dengan pengetahuan yang selanjutnya dapat mewujudkan keahliah atau keterampilan dalam bekerja. Keinginan untuk berbuat baik dari bekerja di vihāra

Dorongan dari luar wanita dewasa awal untuk bekerja juga dipengaruhi oleh gaji, keamanan atau kenyamanan dalam bekerja, hubungan sesama pekerja, pujian, dan pekerjaan tersebut. Motivasi internal dan eksternal merupakan faktor pendukung wanita dewasa awal untuk bekerja di vihāra. Dalam bekerja di vihāra selain kedua faktor tersebut, keinginan untuk berbuat baik juga menjadi salah satu pendorong.

Bekerja di vihāra yang bukan merupakan pilihan awal, tetapi salah satu alternatf pilihan. Dorongan untuk bekerja daripada menganggur, mendapatkan pengalaman dan menabung agar dapat meningkatkan perbaikan sumber daya diri 
dilakukan oleh wanita dewasa awal yang bekerja di vihāra.

Berdasarkan kajian teori faktor-faktor motivasi internal dan eksternal dan latar belakang masalah yang ada, terdapat empat yang menjadi motivasi dasar wanita dewasa awal bekerja di vihāra, yaitu: lowongan pekerjaan di vihāra, keinginan untuk mencari modal, dan berbuat baik atau berdana

Peneliti mencoba menerangkan apa yang ingin peneliti angkat tentang motivasi bekerja pada wanita dewasa awal bekerja di vihāra dengan skema seperti pada gambar 1 .

\section{METODE PENELITIAN}

Penelitian ini termasuk jenis penelitian kualitatif. Penelitian kualitatif pada hakikatnya adalah mengamati orang dalam lingkungan hidupnya, berinteraksi dengan lingkungan hidupnya, dan berusaha memahami pemikiran mereka tentang dunia sekitarnya (Nasution dalam Prastowo, 2012: p. 359). Menurut Denzin and Lincoln (2000: p. 3), penelitian kualitatif merupakan:

... a situated activity that locates the observer in the world. It consists of a set of interpretive, material practices that make the world visible. ... They turn the world into a series of representations, including field notes, interviews, conversations, photographs, recordings and memos to the self.

Penelitian kualitatif merupakan suatu aktivitas yang menempatkan pengamat di dunia. Hal tersebut terdiri dari serangkaian interpretasi, perbuatan atau kebiasaan yang membuat dunia menjadi tampak. pengamat melihat dunia melalui sebuah bagian yang mewakili, termasuk melalui catatan lapangan, wawancara, percakapan, foto, rekaman dan refleksi diri.

Guna mengungkap permasalahan motivasi bekerja di vihāra pada wanita dewasa awal di Vihāra Tanah Putih Semarang, dengan unsur-unsur pokok yang harus ditemukan sesuai dengan butir-butir rumusan masalah, tujuan, dan kegunaan penelitian, maka dalam penelitian ini akan digunakan metode penelitian kualitatif.

Menurut Bogdan dan Taylor (Moleong, 2001: p. 3) metodologi kualitatif merupakan prosedur penelitian yang menghasilkan fakta deskriptif berupa kata-kata tertulis atau lisan dari orang-orang dan perilaku yang diamati. Kirk dan Miller (Moleong, 2001: p. 3) mendeskripsikan bahwa penelitian kualitatif adalah tradisi tertentu dalam ilmu pengetahuan sosial yang secara fundamental bergantung pada pengamatan pada manusia dalam kawasannya sendiri dan berhubungan dengan orang-orang tersebut dalam bahasanya dan dalam peristilahannya.

Penelitian yang bersifat kualitatif ini dilakukan dengan cara mengumpulkan data dari penelitian lapangan (field research) membantu peneliti bagaimana sebenarnya motivasi wanita dewasa awal untuk bekerja di vihāra. Peneliti berusaha untuk melihat sejauhmana motivasi wanita dewasa awal bekerja di vihāra. Kemudian, data akan dianalisis dengan menggunakan metode kualitatif.

Berdasarkan masalah yang diteliti dan tujuannya, maka peneliti menggunakan metode kualitatif fenomenologis. Fenomenologis merupakan pandangan berpikir yang menekankan pada fokus terhadap pengalamanpengalaman subjektif manusia dan interpretasinya. Peneliti dalam pandangan femomenologis berusaha memahami arti peristiwa dan kaitannya terhadap orang-orang yang berada pada situasi tertentu (Moleong, 2001: 17). Sedangkan menurut Husserl (Prastowo, 2012: p. 28), fenomenologi adalah pengalaman subjektif atau pengalaman fenomenologikal; atau suatu studi tentang kesadaran dari perspektif pokok seseorang. Jadi metode kualitatif fenomenologis merupakan prosedur penelitian yang menghasilkan fakta yang deskriptif berupa kata-kata tertulis atau lisan dari orang-orang dan perilaku yang diamati berdasarkan pengalaman subjektif dari seseorang.

\section{Waktu dan tempat penelitian}

Penelitian ini bertempat di Vihāra Tanah Putih Semarang. Vihāra Tanah Putih Semarang dipilih menjadi tempat penelitian karena vihāra tersebut memiliki kegiatan yang beragam. Kegiatan di Vihāra Tanah Puth Semarang terdiri dari Puja Bakti Umum pukul 09.00-11.00 dan 11.00-12.00 WIB, serta Sekolah Minggu untuk anak-anak pukul 09.0011.00 WIB. Ketiga kegiatan tersebut berlangsung setiap Minggu. Kegiatan meditasi untuk umum berlangsung setiap Rabu pukul 19.00-21.00 WIB, dan Jumat pukul 19.00-21.00 WIB kegiatan pemuda. Layanan di Vihāra Tanah Putih Semarang terdiri dari; Buddhist Shop (bursa vihāra), Rumah Abu, Perpustakaan, dan Kantin. Pelayanan umat terdiri dari layanan doa, pernikahan, bakti 
sosial, konseling, mimbar agama Buddha di radio dan televisi, dll.

Vihāra Tanah Putih Semarang memiliki kegiatan workshop dalam bidang seni, ilmu pengetahuan dan teknologi, pendidikan, dan keagamaan. Kegiatan lain seperti; dhamma class, talk show, dan kegiatan hari besar keagamaan. Dalam pelaksanaan aktivitas pelayanan terhadap umat dan kegiatan di vihāra, Vihāra Tanah Putih Semarang memiliki karyawan yang bekerja sebagai cleaning service sejumlah 3 orang, satpam sejumlah 2 orang, dan bursa vihāra sejumlah 2 orang, tenaga administrasi sejumlah 1 orang, dan perpustakaan sejumlah 1 orang. Waktu penelitian dimulai Desember 2011 sampai dengan Maret 2012.

\section{Subjek dan objek penelitian}

Objek dalam penelitian ini adalah Vihāra Tanah Putih Semarang yang difokuskan pada kegiatan rutinitas pelayanan umat dan proses kegiatan vihāra yang dilakukan oleh orang yang bekerja di Vihāra Tanah Puth Semarang. Subjek dalam penelitian ini adalah wanita dewasa awal, lulusan SMA/SMK, Sehat jasmani dan rohani, serta tidak mempunyai cacat fisik yang menyebabkan tidak dapat hidup mandiri, berusia 18-40 tahun, dan bekerja di Vihāra Tanah Putih Semarang, serta mempunyai kapasitas sebagai sumber informasi penelitian yang dipilih secara purposif. Adapun subjek dalam penelitian ini yaitu seorang wanita dewasa awal berusia 21 tahun yang bekerja di vihāra selama 10 bulan dan telah menyelesaikan pendidikan SMK. Subjek saat ini bekerja sebagai sekretaris yayasan dan Vihāra Tanah Putih Semarang. Subjek kedua adalah seorang wanita dewasa awal berusia 19 tahun yang bekerja di vihāra selama 3 bulan dan telah menyelesaikan pendidikan SMA. Subjek saat ini bekerja sebagai sekretaris dan pelayanan Perpustakaan dan Rumah Abu dan Vihāra Tanah Putih Semarang. Subjek ketiga adalah seorang wanita dewasa awal berusia 22 tahun yang bekerja di vihāra selama 14 bulan dan telah menyelesaikan pendidikan SMA. Subjek saat ini bekerja di bagian pelayanan dan penjualan di bursa Vihāra Tanah Puth Semarang.

\section{Teknik pengumpulan data}

Dalam penelitian ini menggunakan teknik observasi dan wawancara. Observasi merupakan istilah yang diarahkan pada kegiatan memperhatikan secara akurat, mencatat fenomena yang muncul dan mempertimbangkan hubungan yang terjalin antara tema. Hasil observasi dicatat dalam sebuah catatan lapangan selengkap-lengkapnya. Dalam penelitian ini, peneliti mengobservasi tentang bahasa tubuh saat diwawancara, perilaku subjek sehari-hari, dan tempat subjek berada/bekerja.

Wawancara diartikan sebagai kegiatan komunikasi verbal antara dua orang atau lebih, satu sebagai pihak pewawancara, dan yang lain sebagai pihak yang diwawancarai, dengan tujuan mendapatkan informasi penting dan gambaran menyeluruh mengenai suatu hal yang ingin diungkap.

Peneliti melakukan indepth interview (wawancara secara mendalam) dengan subjek. Wawancara terhadap perorangan yaitu secara langsung antara pewawancara dengan subjek penelitian. Melalui metode ini diharapkan peneliti dapat mengetahui secara mendalam mengenai motivasi bekerja di vihāra, serta faktor-faktor yang mempengaruhi motivasi serta sikap wanita dewasa awal bekerja di vihāra. Melalui indepth interview ini peneliti hanya mengoleksi data dari informan bukan menghakimi responnya (Patton, 1987: p. 142). Melalui pengoleksian data tersebut, peneliti akan mendeskripsikan ke dalam bahasa akademik berdasarkan data dari wanita dewasa awal yang bekerja di vihāra. Data di-konstruksi melalui interaksi dialog yang komunikatif dan direkam menggunakan Hand Phone Nokia E63.

\section{Teknik keabsahan data}

Teknik pemeriksaan keabsahan data yang dilakukan dalam penelitian ini adalah dengan ketekunan, triangulasi teori dan metode, diskusi dengan teman sejawat, dan perpanjangan keikutsertaan yang merupakan bagian dari kriteria derajat kepercayaan (credibility).

\section{Teknik analisis data}

Teknik analisis data yang digunakan adalah analisis model Miles dan Huberman (1992: p. 16), analisis data secara kualitatif terdiri dari tiga alur kegiatan yang terjadi secara bersamaan, yaitu: reduksi data, penyajian data, dan menarik kesimpulan atau verifikasi data. Data dikumpulkan dengan melakukan klarifikasi dan dianalisis secara kritis dengan menggunakan metode; a) analisis deskriptif, 
yaitu data tentang motivasi bekerja di vihāra pada wanita dewasa awal yang diuraikan secara sistematis; b) analisis interpretasi, yaitu memberi makna atau pemaknaan oleh peneliti melalui analisis.

\section{HASIL PENELITIAN DAN PEMBAHASAN \\ Tema dan Intensitas}

Dari ketiga subjek dapat diketahui bahwa keinginan untuk bekerja di vihāra berdasarkan keinginan sendiri. Meskipun keinginan tersebut dilatarbelakangi tidak adanya lowongan pekerjaan lain yang ketiga subjek ketahui. Keinginan yang muncul pada saat yang berbeda-beda dan dari kejadian dari masing-masing subjek, namum bekerja di vihāra dengan gaji di bawah upah minimum regional merupakan pilihan. Subjek memilih bekerja di vihāra juga di landasi keinginannya untuk mengabdi. Ketiga subjek dalam penelitian telah menyelesaikan pendidikan SMA/SMK dan memiliki keinginan untuk melanjutkan studi atau kursus, maka para subjek bekerja terlebih dahulu.

Ketiga subjek berbuat baik dengan mengabdi ternyata besar faktornya untuk bekerja di vihāra. Pengetahuan berbuat baik dan mengabdi di vihāra ada pada ketiga subjek. Meskipun dilatarbelakangi tidak adanya pekerjaan dan mendapatkan pekerjaan di vihāra, ketiga subjek ingin berbuat baik dan mengabdi sekaligus bekerja. Keinginan ketiga subjek tersebut merupakan salah satu aplikasi dari saddha yang dimiliki. Perbuatan baik (kusala kamma) yang didasari saddha , diyakini ketiga subjek akan menghasilkan kebahagian (kusala kamma vipaka). Buddha menjelaskan dalam Samyutta Nikāya (Bodhi, 2000, p.267), keyakinan merupakan benih yang digunakan untuk mencapai kebahagiaan. Saddha merupakan hal yang paling dasar yang harus dimiliki oleh para perumah tangga untuk mencapai kebahagiaan.

Perbuatan yang menyebabkan keberhasilan atau kebahagiaan merupakan rangkaian proses sebab akibat dan disebut sebagai hukum kamma. Buddha dalam Samyutta Nikāya (Bodhi, 2000, p. 328), Seseorang yang melakukan perbuatan baik (kusala kamma) maka akan memetik hasil perbuatan baik (kusala kamma vipaka) yang dilakukannya. Melalui pemahaman Buddhisme tentang hukum kamma, ketiga subjek melakukan dāna dengan bekerja di vihāra.
Selain hal tersebut, ketiga subjek memahami lingkungan, pekerjaan, dan gaji hasil bekerja di vihāra sebagai cara tersendiri untuk dapat termotivasi dalam bekerja. Dukungan orang tua dan keluarga dengan pemberian ijin dan pengertian membuat subjek dapat bertahan bekerja.

Maslow (Handoko, 1992, p. 20), motivasi manusia dipengaruhi oleh taraf kebutuhannya, mulai dari kebutuhan biologis sampai dengan kebutuhan psikologis yang kompleks, yaitu:

1. Kebutuhan fisiologis (makan, minum, oksigen).

Kebutuhan ini telah tercukupi sejak subjek dalam kandungan, mulai dari asupan makanan, sampai ketika lahir ke dunia subjek menghirup oksigen, minum, buang air besar (BAB) dan kecil (BAK), menggunakan pakaian.

2. Kebutuhan akan rasa aman

Kebutuhan rasa aman juga tercukupi sejak kecil, seperti berada dalam perlindungan dan pantauan orang tua, merasa tentram atau tidak dalam berada tekanan tentang suatu hal, ketika bekerja ada jaminan keselamatan.

3. Kebutuhan akan cinta kasih dan rasa memiliki

Kebutuhan ini dapat diartikan sebagai kebutuhan untuk menjadi bagian dari suatu kelompok atau masyarakat, tampak dengan adanya persahabatan dan interaksi dalam kelompok yang dimiliki subjek, baik itu mulai sejak bersekolah, sampai bekerja, dan didukung dengan kasih sayang yang dicurahkan oleh orang tua dan keluarga sejak kecil.

4. Kebutuhan akan penghargaan

Kebutuhan ini tampak pada timbulnya kepercayaan diri bagi diri sendiri, muncul kemampuan untuk berkompetensi, sehingga orang lain juga menghargai diri kita tentang status, jabatan atau reputasi yang kita miliki.

5. Kebutuhan untuk tahu (pengetahuan, pemahaman, eksplorasi)

Kebutuhan ini meliputi kebutuhan untuk mengetahui dan memahami apa yang ada di luar diri manusia. Kebutuhan untuk mengetahui haruslah dipenuhi terlebih dahulu sebelum kebutuhan untuk memahami 
sesuatu. Selebihnya, pengetahuan yang didapat, harus dikembangkan.

6. Kebutuhan akan keindahan (estetika, keseimbangan, keteraturan)

Kebutuhan ini meliputi kebutuhan akan perasaan keseimbangan dalam proses pembelajaran manusia pembelajaran manusia. Ada pemahaman tentang kealamian yang terjadi dalam proses hidup ini.

7. Kebutuhan akan kebebasan bertindak (aktualisasi diri).

Kebutuhan untuk menjadi diri sendiri dengan mengelurkan segala kemampuan yang dimiliki dalam tingkatan tertinggi perkembangan manusia.

Kebutuhan akan pekerjaan sampai dengan untuk mengabdi atau berbuat baika di vihāra pada subjek menjadi salah satu motivasi bekerja. Subjek yang menginginkan kebutuhannya terpenuhi menjadi pendorong untuk mengabdi. Selain itu, subjek yang memiliki kepercayaan membuat dalam banyak tindakan untuk dengan pemahaman.

Banyak aspek kepribadian subjek terlibat dalam kegiatan pengabdian di vihāra. Salah satu faktor lain terwujud dalam perilaku prososial atau kesukarelaan. Clary dan Synder (Sear, 1999), ada enam fungsi dasar yang menjadikan alasan mengapa seseorang terlibat dalam aktivitas sukarela. Enam fungsi tersebut adalah:

1. Nilai: untuk berekspresi atau bertindak pada nilai yang penting seperti kemanusiaan. Contoh: "saya merasa penting untuk menolong orang lain".

2. Pemahaman: untuk belajar lebih tentang dunia atau melatih keterampilan yang sering digunakan. Contoh: "Dengan bersukarela dalam mengerjakan sesuatu, saya dapat belajar melalui pengalaman langsung".

3. Pengembangan: untuk tumbuh dan berkembang secara psikologis melalui aktivitas sukarela. Contoh: "Melakukan sukarela membuat saya lebih baik dalam mengenal diri saya sendiri".

4. Karier: untuk memperoleh pengalaman yang berhubungan dengan karier. Contoh:
"Melakukan kerja sukarela dapat menolong saya untuk sampai pada tempat di mana saya ingin bekerja".

5. Sosial: untuk memperkuat hubungan sosial. Contoh: "orang-orang yang saya kenal berbagi ketertarikan pada pelayanan masyarakat".

6. Perlindungan: untuk mengurangi perasaan negatif seperti merasa bersalah atau untuk menyelesaikan masalah pribadi. Contoh: "melakukan kerja sukarela adalah pelarian yang baik dari masalah saya sendiri".

Keadaan emosi mampu mempengaruhi perilaku prososial. Hal ini berkaitan dengan faktor-faktor tertentu dalam situasi dan bentuk bantuan yang dibutuhkan. Bantuan yang dibutuhkan melalui motivasi intrinsik dan ekstrinsik secara aktif sampai pada pemahaman kognitif membuat seseorang termotivasi. Efek positif dari motivasi memunculkan perasaan senang setelah dapat bekerja, hal ini dianggap sebagai keuntungan. Dukungan pemahaman terhadap kusala kamma atau berbuat baik dengan mengabdi atau membantu kegiatan di vihāra merupakan wujud dari dāna pada diri subjek.

Berdasarkan hasil diskusi teman sejawat, bekerja di vihāra pada wanita dewasa awal dipengaruhi beberapa faktor utama. Faktor yang mendorong wanita dewasa awal bekerja di vihāra terutama dari dalam diri. Berdasarkan hasil diskusi dengan Ibu Setyaningsih, S.Ag., M.Pd., (Jumat, 7 Januari 2012, di Rumah Setyaningsih, S.Ag., M.Pd.) bahwa bekerja di vihāra sangat dipengaruhi karena tidak adanya lowongan pekerjaan; dari pada menganggur dan malu di masyarakat; keinginan mencari uang untuk dapat memenuhi kebutuhan sendiri, keinginan untuk mencari modal sehingga dapat menabung, memenuhi kebutuhan diri, melanjutkan studi atau mengikuti kursuskursus; dan ingin berbuat baik (kusala kamma) atau lebih pada berdana.

Sedangkan hasil diskusi dengan Bapak Sulistiyo, S.Ag., M.Ag., dan Bapak Suhantojo, S.Pd., (Rabu, 12 Januari 2012, di gedung Thomas Aquinas lantai 4, ruang 4.21 Unika Soegijapranata Semarang) yang merupakan teman studi peneliti. Kedua teman peneliti tersebut merupakan orang yang sering 
membantu kegiatan dan tinggal di tempat Ibadahnya dan pernah melakukan observasi serta wawancara tentang motivasi para pekerja dewasa awal bekerja di tempat ibadah. Diskusi tersebut memberikan kesimpulan bahwa bekerja di tempat ibadah dilatar belakangi untuk mencari uang dan memenuhi kebutuhan; terdesak ekonomi; pengabdian pada agama; mencari pengalaman; dan menambah perbuatan baik.

Berdasarkan hasil diskusi dengan teman sejawat di atas dapat diketahui motivasi bekerja di vihāra pada masa dewasa awal didorong karena adanya lowongan pekerjaan di tempat ibadah, keinginan untuk mencari modal, mencari pengalaman, dan berbuat baik dengan mengabdi. Hasil diskusi dengan teman sejawat tersebut relevan dengan beberapa tema yang muncul berkaitan dengan motivasi bekerja di vihāra pada wanita dewasa awal, antara lain:

1. Lowongan pekerjaan di vihāra

Perlu di ketahui seorang dapat bekerja di vihāra khususnya di kota di pengaruhi lowongan pekerjaan di vihāra tersebut. Selain pada dasarnya pada ketiga subjek tidak memiliki pekerjaan dan dari pada menganggur. Lowongan pekerjaan ini adalah salah satu tema dalam penelitian. Perlu diketahui bahwa selama melakukan wawancara dan observasi, ketiga subjek bekerja di vihāra.

Pada subjek I, lowongan pekerjaan di vihāra tampak mempengaruhi sangat besar subjek bekerja di vihāra. Karena subjek mengalami kejenuhan waktu bekerja di perusahaan-perusahaan sebelumnya. Subjek ingin mendapatkan suasana baru dan bekerja di vihāra dianggap subjek lebih damai dan tentram. Subjek juga mendapat dukungan dari orang tua untuk bekerja di vihāra karena dapat membantu di vihāra. Motivasi bekerja subjek terwujud dengan bekerja secara disiplin dan rapi serta hari minggu tetap bekerja.

Pada subjek II, lowongan pekerjaan di vihāra tampak mempengaruhi sangat besar. Karena subjek perasaan tidak menyenangkan sewaktu bekerja di swalayan menjadikan subjek keluar. Pengalaman subjek menganggur di rumah dan hanya membantu orang tua membuat subjek berkeinginan bekerja kembali. Subjek bekerja di vihāra juga ingin belajar lebih dekat dengan Agama Buddha. Pengetahunan yang luas tentang agama sangat diharapkan oleh subjek. Keluarga mendukungan subjek untuk dari bekerja di vihāra dan menambah pengetahuan tentang agama. Motivasi bekerja subjek terwujud dengan bekerja secara dengan semangat.

Pada subjek III, lowongan pekerjaan di vihāra tampak terwujud dengan bekerja displin dan bersemangat. Subjek dapat bekerja di vihāra berkat informasi dari kakak sepupunya. Subjek mulai bekerja langsung di tempatkan di bursa vihāra. Selama satu tahun 2 bulan bekerja, motivasi bekerja subjek untuk bekerja sangat besar. Hal tersebut diketahui dari aktivitas subjek di bursa dan dalam senggang waktu masih menyempatkan membaca dan menulis novel. Pengalaman menganggur, melamar pekerjaan berulang kali, dan sekarang dapat bekerja dimanfaatkan dengan baik oleh subjek. Bagi subjek waktu dapat dimanfaatkan dengan mengerjakan segala sesuatu yang bermanfaat.

2. Keinginan untuk mencari modal

Ketiga subjek bekerja di vihāra berkeinginan untuk dapat memperoleh modal bagi masa depan. Bekerja dan menabung sehingga dapat melanjutkan kuliah atau mengikuti kursus merupakan harapan ketiga subjek.

Pada subjek I, keinginan mencari modal untuk dapat membiayai kuliah dari hasil bekerja. Subjek mempunyai motivasi bahwa dengan bekerja akan merubah hidupnya. Hal ini diperkuat usaha subjek tetap berusaha meningkatkan kompetensi dengan kursus Bahasa Mandarin. Subjek melakukan kursus di luar jam bekerja, karena merasa tidak mengetahui Bahasa Mandarin dan didorong dari rasa sukanya. Motivasi subjek untuk dapat berkuliah lagi juga cukup tinggi dengan tetap berusaha melanjutkan studi kembali dengan hasil kerja. Subjek juga akan beralih pada profesi lain yang lebih menjanjikan apabila ada profesi lain yang lebih menguntungkan untuk masa depan. Selain hal tersebut subjek berharap dapat memiliki keahlian agar dapat bekerja dan mendapat gaji yang mencukupi kebutuhan hidup.

Pada subjek II, keinginan mencari modal untuk memenuhi kebutuhan dan meringankan beban orang tua. Subjek juga menabung untuk dapat memiliki modal agar dapat melanjutkan kuliah atau kursus. Subjek memilih kursus apabila tidak dapat melanjutkan kuliah, karena hal tersebut untuk masa depan subjek. Hal tersebut membuat subjek dapat 
bekerja, mempunyai modal untuk merubah kehidupan serta merealisasikan cita-cita.

Pada subjek III, keinginan mencari modal untuk dapat melanjutkan kuliah atau mengikuti kursus. Subjek berusaha mandiri dengan membiayai kebutuhannya sendiri karena dengan usia yang cupuk dewasa subjek juga memerlukan modal untuk masa depan. Subjek juga berkeinginan memiliki usaha sendiri, dari hasil mengelola bursa subjek berharap pengalaman tersebut dapat digunakan saat mampu berwiraswasta.

3. Mencari pengalaman

Pengalaman merupakan sesuatu yang berharga bagi orang yang bekerja. Pengalaman tersebut dapat menjadi bekal dalam bekerja atau beradaptasi pada lingkungan pekerjaan yang baru. Mencari pengalaman dalam bekerja merupakan harapan umum bagi setiap individu, seperti halnya ketiga subjek dalam penelitian ini.

Pada subjek I, mencari pengalaman ingin membedakan pekerjaan di vihāra dengan di perusahaan dan berkeinginan mencari suasana baru. Pengalaman bekerja di vihāra bagi subjek lebih pada organisasi dan mengelola yayasan. Subjek juga beranggapan bila di vihāra lebih tentram dan damai. Dengan pengalaman, subjek dapat menguasai pekerjaan dan memanejemen dengan baik, yang didukung suasana kerja yang kondusif.

Pada subjek II, mencari pengalaman ingin membandingkan dengan pekerjaan di swalayan tempat subjek pertama kali bekerja. Subjek bekerja di vihāra juga ingin mengenal lebih dekat Agama Buddha, mengenal bhikkhu, dan umat, serta dapat mengikuti acara di vihāra. Pengalaman bekerja di vihāra memperluas pengetahuan agama dan bermanfaat bagi subjek. Subjek mendapatkan pengalaman dari orang-orang yang berada di lingkungan vihāra serta belajar agama.

Pada subjek II, mencari pengalaman ingin mendapatkan pengalaman dalam mengelola bursa. Bekerja di vihāra membuat subjek dapat mengaplikasikan ide kreatifnya dan dapat di jual. Subjek merasa cocok bekerja di bursa vihāra. Selain hal tersebut subjek juga dapat berinteraksi dengan para umat serta berbagi pengalaman, sehingga menambah wawasan subjek. Subjek dari awal sudah mengetahui bahwa bekerja di vihāra dengan gaji sedikit atau di bawah upah minimum regional, tetapi subjek memotivasi diri yang Jurnal Agama Buddha dan Ilmu Pengetahuan Vol I No. 1 September 2014 terpenting adalah pengalaman dan pengetahuan. Dengan pengalaman dan pengetahuan serta hobi maka minat keterampilannya subjek tersalurkan.

4. Berbuat baik dengan mengabdi

Berbuat baik dalam agama Buddha di kenal dengan kusala kamma. Kusala kamma merupakan perbuatan baik yang disertai kehendak melalui pikiran, ucapan, dan badan jasmani (fisik). Perbuatan baik dapat dilakukan dengan berbagai cara salah satunya adalah dengan mengabdi atau membantu di vihāra, dan melalui wawancara serta observasi ketiga subjek tersebut menunjukkan keinginannya untuk berbuat baik dengan mengabdi.

Pada subjek I, berbuat baik dengan mengabdi bermakna dengan bekerja di vihāra subjek dapat melayani umat dan para bhikkhu. Subjek bekerja di vihāra juga mendapatkan dukungan dari orang tua. Bagi subjek, dengan bekerja mendorong subjek untuk mengabdi, bukan hanya untuk mencari uang. Subjek juga merasa senang dapat berbuat baik dan bekerja di vihāra.

Pada subjek II, berbuat baik dengan mengabdi di vihāra merupakan perbuatan baik. Selain untuk mencukupi kebutuhan bekerja di vihāra juga lebih pada pengabdian. Pengetahuan subjek bekerja di vihāra merupakan perbuatan baik wujud dari pengabdian. Pengetahuan berbuat baik dan pengabdian tersebut menjadikan subjek termotivasi bekerja di vihāra.

Pada subjek III, berbuat baik dengan bekerja di vihāra merupakan suatu pengabdian dan gaji tidak menjadi masalah. Dengan mengabdi subjek dapat belajar agama. Kondisi subjek yang berhadapan dengan banyak literatur membuat wawasan sumbek bertambah. Selain melayani bhikkhu atau samanera berinteraksi dengan umat merupakan wujud pelayanan yang membuat subjek merasa nyaman dan bahagia. 
Dari hasil observasi dan wawancara yang dilakukan terhadap ketiga subjek, dapat dibuat tabel sebagai berikut:

\begin{tabular}{|c|c|c|c|c|}
\hline Tema & S.1 & S.2 & S.3 & Kesimpulan \\
\hline $\begin{array}{l}\text { Lowongan } \\
\text { pekerjaan } \\
\text { di vihāra }\end{array}$ & $\begin{array}{c}++ \\
+\end{array}$ & $\begin{array}{c}++ \\
+\end{array}$ & $\begin{array}{c}++ \\
+\end{array}$ & $\begin{array}{l}\text { Lowongan pekerjaan di } \\
\text { vihāra sangat } \\
\text { mendukung subjek untuk } \\
\text { dapat bekerja. } \\
\text { Subjek I mendapat } \\
\text { suasana baru, Subjek II } \\
\text { dapat belajar agama, dan } \\
\text { Subjek III bermanfaat } \\
\text { dengan baik. }\end{array}$ \\
\hline $\begin{array}{l}\text { Keinginan } \\
\text { untuk } \\
\text { mencari } \\
\text { modal }\end{array}$ & $\begin{array}{l}++ \\
++\end{array}$ & $\begin{array}{c}++ \\
+\end{array}$ & ++ & $\begin{array}{l}\text { Keinginan untuk mencari } \\
\text { modal agar dapat } \\
\text { melanjutkan kuliah atau } \\
\text { mengikuti kursus agar } \\
\text { masa depannya lebih } \\
\text { baik. }\end{array}$ \\
\hline $\begin{array}{l}\text { Mencari } \\
\text { pengalaman }\end{array}$ & $\begin{array}{c}++ \\
+\end{array}$ & $\begin{array}{c}+ \\
+\end{array}$ & ++ & $\begin{array}{l}\text { Ketiga subjek mencari } \\
\text { pengalaman dengan } \\
\text { bekerja di vihāra. } \\
\text { Subjek I untuk masa } \\
\text { depan. } \\
\text { Subjek II mengenal } \\
\text { agama dan umat. } \\
\text { Subjek III menyalurkan } \\
\text { ide-ide kreatif. }\end{array}$ \\
\hline $\begin{array}{l}\text { Berbuat } \\
\text { baik }\end{array}$ & $\begin{array}{c}++ \\
+\end{array}$ & $\begin{array}{c}++ \\
+\end{array}$ & $\begin{array}{c}++ \\
+\end{array}$ & $\begin{array}{l}\text { Mengabdi merupakan } \\
\text { perbuatan baik yang } \\
\text { harus dilakukan subjek } \\
\text { yang bekerja di vihāra. }\end{array}$ \\
\hline
\end{tabular}

Berdasarkan hal di atas maka dapat dilihat bahwa dari ketiga subjek yang telah peneliti temui, ketiga subjek mempunyai motivasi bekerja di vihāra setelah melakukan pemenuhan kebutuhan yang lain. Hal ini tampak motivasi subjek yang berujung pada harapan masa depan lebih baik dan ingin berbuat baik dengan mengabdi di vihāra, yang artinya bekerja dapat memenuhi kebutuhan secara mandiri, dengan harapan dapat hidup lebih layak melalui pengetahuan dan keterampilan yang diperoleh dan akhirnya dapat berbuat baik dilingkungan vihāra dan dengan melayani para umat terutama bhikkhu dan samanera yang tinggal di vihāra.

\section{Dinamika Psikologis}

Subjek pertama masih membutuhkan kebutuhan fisiologis sebagai hal utama dalam hidup. Subjek juga membutuhkan rasa aman, karena lingkungan vihāra yang nyaman dalam bekerja merupakan pilihan. Dalam kebutuhan dimiliki dan dicintai subjek mendapatkan dengan melakukan interaksi dengan umat di vihāra. Subjek juga membutuhkan kebutuhan akan pengakuan diri, subjek melakukan pekerjaan atas nama pribadi untuk tujuan pengembangan hidup.

Kebutuhan kognitif sangat dibutuhkan subjek, hal ini terbukti di luar jam kerja subjek mengikuti kursus Bahasa Mandarin, dan ingin melanjutkan studinya di USM. Subjek telah sampai dalam tahapan kebutuhan akan estetika, karena bagi subjek apapun yang terjadi di dunia ini merupakan proses yang wajar dan dapat menjadi baik apabila sekarang dikondisikan dengan baik. Kebutuhan aktualisasi diri subjek belum nampak. Hal ini terjadi sebab subjek menekankan pada kebutuhan-kebutuhan yang lain. Beberapa kebutuhan tersebut yang belum terpenuhi mempengaruhi motivasi subjek bekerja di vihāra.

Subjek kedua masih membutuhkan kebutuhan fisiologis sebagai hal utama dalam hidup. Subjek bekerja di vihāra karena ingin mendapatkan rasa aman dibanding dengan bekerja di swalayan sebelum subjek keluar. Subjek membutuhkan rasa dimiliki dan dicintai oleh setiap orang yang berada di vihāra. Kebutuhan pengetahuan dan keterampilan sangat dibutuhkan oleh subjek, oleh sebab itu subjek berkeinginan untuk dapat berkuliah dan menjadi guru. Kebutuhan akan estetika sangat subjek butuhkan dalam lingkungan kerja. Subjek belum dapat mengaktualisasikan diri dengan baik, sebab kebutuhan-kebutuhan lain belum terpenuhi. Kebutuhan dasar yang belum terpenuhi mendorong subjek untuk bekerja, mencari modal, pengalaman, dan berbuat baik.

Subjek ketiga masih membutuhkan kebutuhan fisiologis sebagai hal utama dalam hidup. Subjek memerlukan rasa aman, karena subjek sebagai wanita dewasa awal yang menginginkan rasa aman untuk dapat bekerja dengan nyaman. Subjek juga membutuhkan rasa dimiliki dan dicintai oleh teman-teman dan para umat. Subjek membutuhkan pengakuan diri, karena setiap karya tulisan atau kreatifitas subjek dapat membantu masa depannya.

Kebutuhan pengetahuan subjek sangat diperlukan. Subjek ingin melanjutkan studi dan kursus serta dapat membuka usaha. Kebutuhan estetika bagi subjek merupakan bagian dari keindahan yang membantu memajukan pengetahuan dan kreativitas dalam usahanya. Subjek sambil bekerja beberapa kali mengaktualisasikan dirinya dengan membuat cerpen dan menulis novel.

Dengan melihat hasil penelitian di atas, dapat disimpulkan bahwa subjek dalam penelitian mempunyai motivasi bekerja di 
vihāra. Hal ini karena dipengaruhi kebutuhan yang belum terlewati pada penjabaran hierarki kebutuhan Maslow, sehingga ketiga subjek bekerja di vihāra. Selain itu keyakinan subjek pada kusala kamma yang akan menghasilkan kebajikan atau kebahagiaan bagi pelakunya, membuat subjek mengabdi atau berbuat baik.

Dari hasil tersebut digambarkan hubungan antar tema yang muncul sehubungan dengan motivasi bekerja di vihāra pada wanita dewasa awal yang telah dilalui oleh ketiga subjek. Skema kasus gabungan dapat dilihat seperti pada gambar 2 .

\section{SIMPULAN DAN SARAN Simpulan}

Motivasi wanita dewasa awal bekerja di vihāra adalah dorongan wanita yang berusia 1922 tahun yang mengarahkan tingkah laku untuk mencapai tujuan peran dan tanggung jawabnya sebagai individu di tempat ibadah umat Buddha. Banyak faktor dan/atau komponen yang dapat mempengaruhi motivasi seseorang, baik dari dalam diri individu itu sendiri maupun dari luar individu dan keseluruhan tersebut akan tampak dalam kematangan dan kedewasaan kepribadian seorang individu dalam kehidupannya sehari-hari. Adapun faktor-faktor yang dapat mempengaruhi motivasi ada pada diri individu itu sendiri misalnya kemampuan dan kematangan pribadinya serta lingkungan sekitar di mana individu, berada misalnya keluarga dan lingkungan sosialnya. Diketahui motivasi bekerja di vihāra pada masa dewasa dini didorong karena adanya lowongan pekerjaan di tempat ibadah, keinginan untuk mencari modal, mencari pengalaman, dan berbuat baik dengan mengabdi.

Lowongan pekerjaan di vihāra sangat mendukung subjek untuk dapat bekerja. Subjek I mendapat suasana baru, subjek II dapat belajar agama, dan subjek III dengan bekerja di vihāra membawa manfaat. Keinginan untuk mencari modal agar dapat melanjutkan kuliah atau mengikuti kursus agar masa depannya lebih baik dan dapat memenuhi kebutuhan hidup. Ketiga subjek mencari pengalaman dengan bekerja di vihāra. Subjek I mencari pengalaman untuk masa depan, subjek II mencari pengalaman untuk mengenal agama dan umat, dan subjek III mencari pengalaman untuk menyalurkan ide-ide kreatif. Mengabdi merupakan perbuatan baik yang harus dilakukan subjek yang bekerja di vihāra.
Ketiga subjek mempunyai motivasi bekerja di vihāra setelah melakukan pemenuhan kebutuhan yang lain. Hal ini tampak motivasi subjek yang berujung pada harapan masa depan lebih baik dan ingin berbuat baik dengan mengabdi di vihāra, yang artinya berbuat baik dengan kusala kamma. Kusala kamma merupakan perbuatan baik yang disertai kehendak melalui pikiran, ucapan, dan badan jasmani (fisik). Perbuatan baik dapat dilakukan dengan berbagai cara salah satunya adalah dengan mengabdi atau membantu di vihāra. Bekerja dapat memenuhi kebutuhan secara mandiri, dengan harapan dapat hidup lebih layak melalui pengetahuan dan keterampilan yang diperoleh dan akhirnya dapat berbuat baik di lingkungan vihāra dan dengan melayani para umat terutama bhikkhu dan samanera yang tinggal di vihāra.

\section{Saran}

Mengingat bahwa subjek telah memiliki motivasi bekerja di vihāra, maka diharapakan subjek mampu lebih dalam memotivasi diri dalam bekerja untuk bekal masa depan subjek. Memahami ajaran agama dengan mengabdi memang diperlukan tetapi subjek juga harus memikirkan masa depan subjek selanjutnya. Subjek harus tetap belajar, sebab dengan pengetahuan dan keterampilan hidup subjek akan lebih baik dan semakin mantap dalam pengabdian atau membantu bagi vihāra, sesama maupun makhluk lain.

Peneliti lain yang akan mengadakan penelitian serupa dapat memilih subjek penelitian yang lebih representative dalam jumlah yang lebih banyak sehingga penelitian lebih baik dan akurat. Dalam pemilihan subjek, diharapkan dapat memiliki waktu yang lebih lama untuk melakukan wawancara dan observasi.

\section{Daftar Pustaka}

Anoraga, P dan Suyati, S. (1995). Perilaku Keorganisasian. Jakarta: Dunia Pustaka.

Azami, Syuwi. (2009). Motivasi Kerja pada Guru Honorer. Hasil Penelitian. Depok: Fakultas Psikologi Universitas Gunadharma.

Bodhi (Trans.). (2000). The Connected Discourses of the Buddha Vol. I 
(Samyutta Nikāya). Oxford: The Pali Text Society.

Davids, Rhys and William Stede (Ed). (1992). The Pali Text Society's Pali-english Dictionary. Oxford: The Pali Text Society.

Denzin, K. N dan Lincoln. (2009). Handbook of Qualitative Research. Yogyakarta: Pustaka Pelajar.

Greenberg, J dan Robert, A. B. (2003). Behavior in Organizations: Understanding and Managing The Human Side of Work. Third Edition. Allin and Bacon. A Division of Schuster. Massachuscets.

Handoko M. (1992). Motivasi Daya Penggerak Tingkah Laku Cetakan ke IX. Yogyakarta: Kanisius.

Hare. (2001). The Book of Gradual Sayings (Anguttara Nikāya). Oxford: The Pali Text Society.

Horner (Trans.). (2002). The Middle Length Sayings Vol. III (Majjhima Nikāya). Oxford: The Pali Text Society.

Hurlock, E. B. (1980). Developmental Psychology, A Life-Span Approach: Psikologi Perkembangan, Suatu Pendekatan Sepanjang Rentang Kehidupan. (Terjemahan Istiwidayanti dan Soejarwo). Jakarta : Erlangga.

Masefield, Peter (Trans). (2001). The Itivuttaka. Oxford: The Pali Text Society.

Moleong L.J. (2001). Metodologi Penelitian Kualitatif. Bandung: Remaja Rosdakarya.

Panjika. (2004). Kamus Umum Buddha Dhamma. Jakarta: Tri Satva Buddhist Centre.

Patton. (1987). Qualitative Evaluation Methods. Beverly Hills: Sage Publication.

Prabu, Anwar. (2005). Pengaruh Motivasi Terhadap Kepuasan Kerja Pegawai Badan Koordinasi Keluarga Berncana Nasional Kabupaten Muara Enim.
Jurnal Manajemen \& Bisnis Sriwijaya. Vol. 3. No 6.

Prastowo, A. (2012). Metode Penelitian Kualitatif dalam Perspektif Rancangan Penelitian. Jogjakarta: Ar-Ruzz Media.

Purwanto N.M. (2007). Psikologi Pendidikan. Bandung: Remaja Rosdakarya.

Santrock, J.W. (2002). Life Span Development. Alih bahasa: Achmad Chusairi \& Juda Damanik. Jakarta: Erlangga.

Sear, David O. (1999). Psikologi Sosial. Edisi ke-5. Jakarta: Erlangga.

Tim Penyusun. (2008). Kamus Besar Bahasa Indonesia. Jakarta: Pusat Bahasa Departemen Pendidikan Nasional.

Turner, J. S. dan Helms, D. B. (1995). Life-span development. 5 th ed. Forth wort: Harcout Brace College Publisher.

Wade, C dan Carol T.( 2007). Psikologi. Jakarta: Erlangga.

Weiner, B. 1982. Theories of Motivation from Mechanism to Cognition. Chicago: Mark Co.

Widya, D. K. (2005). Kompilasi Istilah Buddhis. Jakarta: Yayasan Dana Pendidikan Buddhis Nalanda. 
Gambar 1

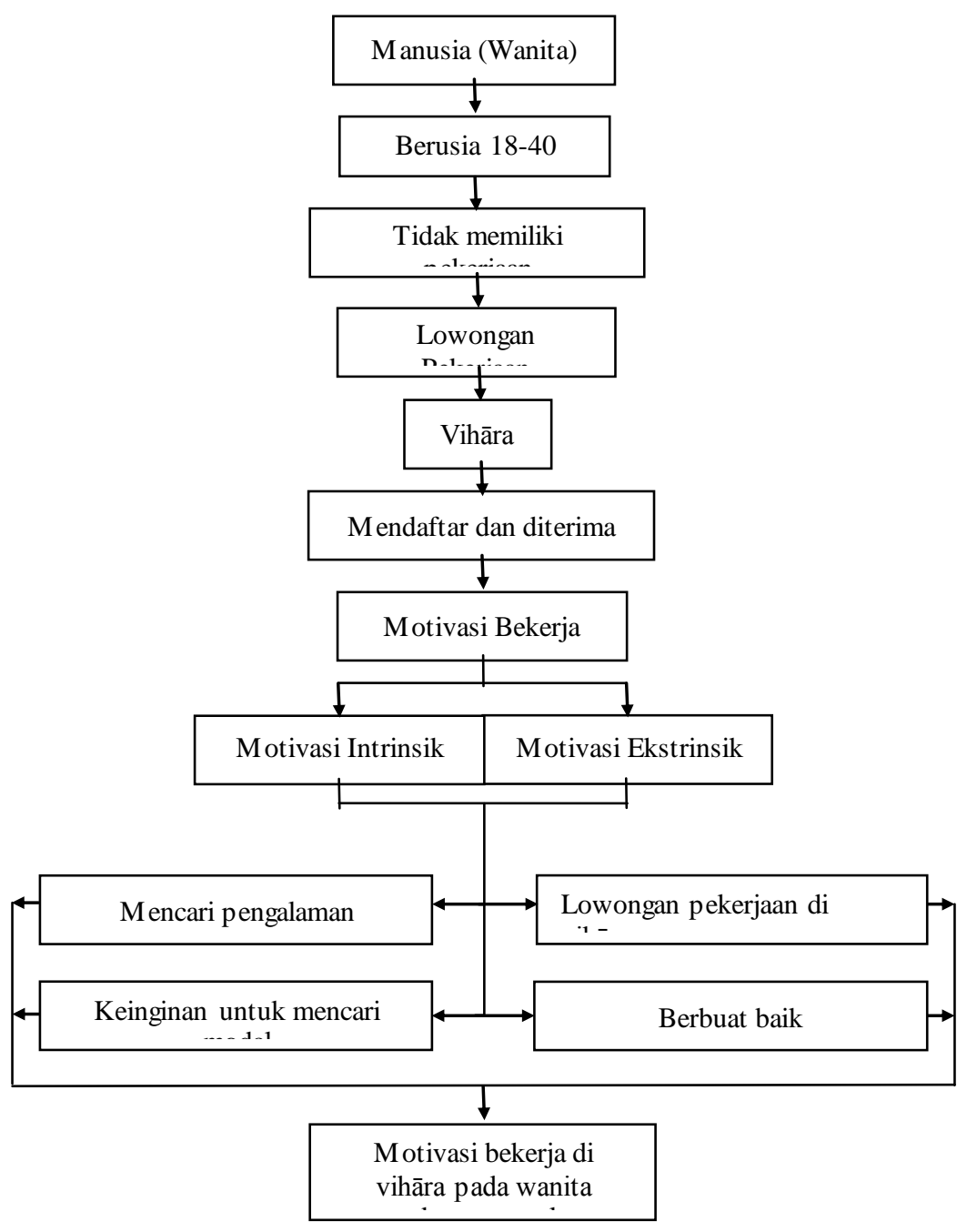


Gambar 2

\section{Skema Kasus Gabungan}

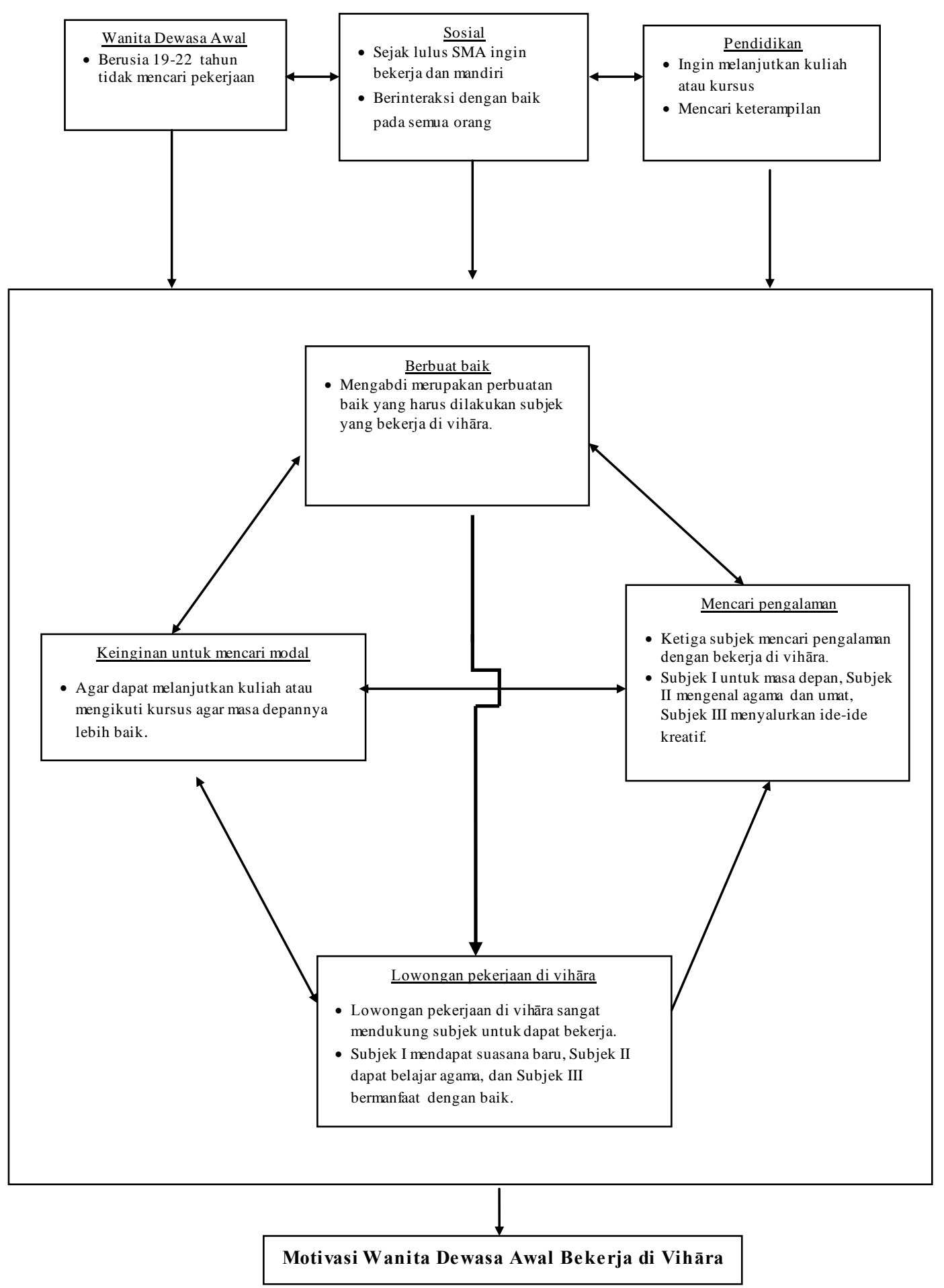




\title{
PENGEMBANGAN MODEL ASESMEN OTENTIK PADA PENDIDIKAN AGAMA BUDDHA DI SEKOLAH DASAR DALAM RANGKA PENINGKATAN KINERJA GURU
}

\author{
THE DEVELOPMENT OF AUTHENTIC ASSESSMENT MODEL ON BUDDHIST \\ EDUCATION IN PRIMARY SCHOOL IN THE CONTEXT OF TEACHERS' PERFORMANCE \\ IMPROVEMENT
}

Tri Yatno, Hesti Sadtyadi, Hariyanto, Novianti, Urip Widodo, Sukodoyo

Triyatno920@yahoo.com.15hestisadtyadi@gmail.com.

\begin{abstract}
Abstrak
Model pengembangan dalam penelitian ini adalah mengembangkan MAO dalam pembelajaran pendidikan agama Buddha. MAO yang dikembangkan merupakan model assessment for learning. Penyusunan MAO meliputi penyusunan model, validasi pakar, dan melatih guru. Analisis data dalam penelitian awal adalah pendekatan deskriptif, sedangkan analisis pengembangan model adalah pendekatan kualitatif dan kuantitatif. Hasil pengamatan menunjukkan bahwa keterlaksanaan MAO uji coba terbatas sebesar 3,75 lebih rendah dibandingkan dengan uji coba luas sebesar 3,92. Beberapa faktor yang diduga menjadi penyebab kondisi tersebut adalah pembelajaran yang berbeda dari sebelumnya, sehingga membutuhkan waktu untuk penyesuaian muatan aktivitas yang dilakukan dalam pembelajaran juga bebeda. Perasaan canggung diamati oleh pengamat, dan siswa belum siap menghadapi situasi yang baru. Berbeda dengan pengamatan keempat bahwa semua aktivitas yang telah direncanakan telah dapat direalisasikan semuanya oleh guru. Hasil pengamatan keterlaksanaan implementasi MAO dalam kelas di satu Kabupaten, satu Karesidenan dan dalam satu Provinsi berhasil dengan baik dan selalu mengalami peningkatan.
\end{abstract}

Kata Kunci: pengembangan asesmen otentik, pendidikan agama Buddha

\begin{abstract}
The development model in this research was to develop the MAO in Buddhism learning. The developed MAO is assessment for learning model. The MAO preparation includes of modeling, expert validation, and teachers training. The data analysis in the initial study was a descriptive approach, while the analyses of the model development were qualitative and quantitative approach. The observation results showed that the enforceability of MAO in limited testing of 3.75 lower than the wide test of 3.92. Several factors are thought to be the cause of this condition is different from the previous study, so it takes time to activities charge adjustments made in the different learning. The awkward feeling observed by the observer, and the student is not ready to face the new situation. Unlike to the fourth observation, that all of the planned activities have been realized by the teacher. The observations of MAO implementation in the classroom in the one district, one residency and in one province are work well and always increase.
\end{abstract}

\section{Keywords: authentic assessment development, Buddhism education}

PENDAHULUAN

Asesmen penting dalam proses pendidikan untuk mengetahui sejauh mana hasil belajar siswa. Menurut Fran Hagstrum (2006) peningkatan kualitas pendidikan memerlukan perbaikan proses pembelajaran di sekolah dengan menerapkan cara kerja sistematis yang salah satu diantaranya dapat dimulai dari pembenahan sistem asesmen (penilaian). Artinya dalam usaha perbaikan sistem pembelajaran di sekolah, diperlukan sejumlah informasi yang diperoleh dari hasil kegiatan asesmen yang dilakukan secara sistematis dan profesional oleh guru atau instansi pendidikan.

Pelaksanaan asesmen yang selama ini digunakan dalam pembelajaran pendidikan agama Buddha menggunakan tes tertulis 
berbentuk tes pilihan ganda, isian, maupun uraian. Penilaian dilakukan secara terencana yakni dilakukan melalui ulangan harian maupun ulangan akhir semester. Hasil belajar siswa yang hanya ditunjukkan dengan nilai ulangan harian dari setiap bidang studi dan kebiasaan tersebut dilakukan secara terus-menerus menyebabkan berkurangnya kreativitas siswa (Munif Chatib, 2011: p. 145-146).

Penelitian Philip dan John (1997) berkaitan dengan hasil belajar siswa dalam pendidikan agama, bahwa pendidikan agama berbeda dengan pendidikan lainnya seperti pendidikan matematika, sains, dan sejarah. Demikian pula dengan pendidikan agama Buddha. Strategi penilaian evaluasi hasil belajarnya berbeda, tidak hanya dilihat dari hasil tes tetapi dari proses pembelajaran di kelas. Munif Chatib (2011:71) menjelaskan bahwa kecerdasan seseorang tidak dibatasi oleh indikator-indikator yang ada dalam achievement test (tes formal). Setelah dilakukan penelitian, kecerdasan seseorang selalu berkembang (dinamis), tidak statis. Tes yang dilakukan untuk menilai kecerdasan seseorang, praktis hanya menilai kecerdasan pada saat itu, tidak untuk satu bulan lagi, atau sepuluh tahun ke depan. Hal tersebut menunjukkan bahwa kecerdasan siswa selalu mengalami perubahan dan berkembang sesuai dengan hal yang dipelajari.

Dalam Digha Nikaya (Mahagovinda Sutta, 11-12: p. 290), dijelaskan bahwa Sang Buddha sebagai guru melakukan sesuatu yang beliau katakan dan mengatakan sesuatu yang beliau lakukan dalam setiap aspek ajarannya. Selanjutnya dijelaskan pula bahwa Sang Buddha telah melampaui keragu-raguan, menjawab pertanyaan "mengapa" dan "bagaimana", mencapai tujuannya sehubungan dengan cita-citanya dan kehidupan suci yang tertinggi. Guru-guru agama Buddha semestinya meneladani sikap Sang Buddha tersebut dalam hal pembelajaran sehingga tujuan dari pembelajaran pendidikan agama Buddha dapat tercapai. Guru memberikan materi pendidikan agama Buddha pada siswa dengan mengaplikasikannya dalam kegiatan belajar siswa di kelas. Dalam melakukan evaluasi belajar siswa, guru memberikan pertanyaan yang membuat siswa untuk berpikir kritis dengan menggunakan kata tanya "mengapa" dan "bagaimana". Bentuk-bentuk pertanyaan seperti ini memberikan jawaban yang luas dan membuat belajar siswa lebih bermakna.

Teori Multiple Intelligences menawarkan perubahan yang cukup fundamental dalam penilaian sebagai output sebuah proses pembelajaran. Teori ini menganjurkan sistem yang tidak bergantung pada tes standar atau tes yang didasarkan pada nilai formal melainkan didasarkan pada penilaian otentik yang mengacu pada kriteria khusus dengan menggunakan tes yang memiliki titik acuan spesifik dan tes yang memandingkan prestasi siswa saat ini dengan prestasi yang lalu.

Teori selanjutnya adalah Taksonomi Bloom yang telah direvisi oleh Anderson. Adapun batasan penilaian kompetensi yaitu tes tunggal tidak cukup untuk memberikan gambaran/informasi tentang kemampuan, ketrampilan, pengetahuan, dan sikap seorang siswa. Selanjutnya penilaian tidak mutlak karena siswa terus berkembang sesuai dengan pengalaman belajar yang dialaminya. Berikut digambarkan domain kognisi:

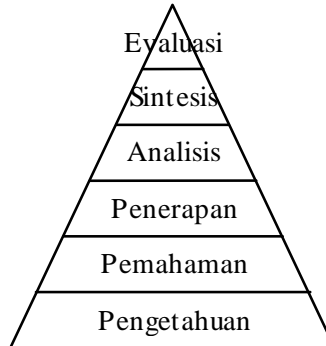

Taksonomi

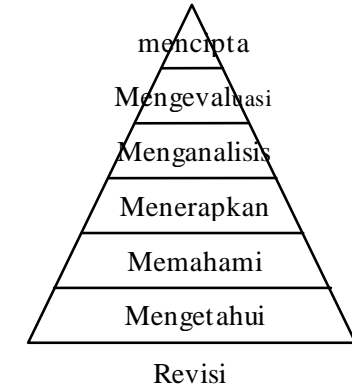

Gambar 1. Revisi domain kognisi (Muhammad Yaumi, 2013: p. 93)

Berdasarkan gambar tersebut tampak bahwa domain kognisi pengetahuan (Bloom) atau mengetahui (revisi Anderson) menempati urutan bawah yang berarti itu pengalaman belajar yang paling dasar. Padahal tes yang biasanya dilakukan oleh guru baru mengukur pengetahuan siswa. Meskipun ada pula yang telah mengukur sintesis tetapi itu belum maksimal apalagi domain kognisi evaluasi belum terukur sehingga pengalaman belajar siswa belum terukur secara keseluruhan.

Menurut Permendiknas Nomor 2 Tahun 2006 tujuan pendidikan agama Buddha diantaranya siswa dapat memiliki kemampuan dalam (1) mengembangkan keyakinan (Saddha) dan ketakwaan (Bhakti) kepada Tuhan Yang Maha Esa, Tiratana, Bodhisattva dan Mahasattva; (2) mengembangkan manusia Indonesia yang berakhlak mulia melalui peningkatan pelaksanaan moral (Sila), meditasi (Samadhi) dan kebijaksanaan (Panna) sesuai 
dengan Buddha Dharma (Agama Buddha); (3) mengembangkan manusia Indonesia yang memahami, menghayati, dan mengamalkan/menerapkan Dharma sesuai dengan Ajaran Buddha yang terkandung dalam Kitab Suci Tipitaka/Tripitaka, sehingga menjadi manusia yang bertanggung jawab sesuai dengan prinsip Dharma dalam kehidupan sehari-hari; (4) memahami agama Buddha dan sejarah perkembangannya di Indonesia.

Kompetensi yang harus dicapai dalam pendidikan agama Buddha SD tersebut menuntut beragamnya alat ukur yang digunakan sebagai penilaian. Berdasarkan wawancara dengan guru agama Buddha " $X$ ", tentang alat penilaian yang digunakan untuk mengukur hasil belajar siswa, sejauh ini masih menggunakan tes tertulis dalam bentuk pilihan ganda, isian, dan uraian. Hasil belajar yang dinilai meliputi ranah kognitif, afektif dan psikomotor sehingga untuk mengungkap secara menyeluruh ketiga ranah tersebut diperlukan asesmen otentik, yaitu proses pengumpulan informasi oleh guru tentang perkembangan dan pencapaian pembelajaran yang dilakukan oleh siswa melalui berbagai teknik yang mampu mengungkapkan, membuktikan serta menunjukkan secara tepat bahwa tujuan pembelajaran dan kemampuan (kompetensi) telah benar-benar dikuasai dan capai (Bahrul Hayat, 2010: p. 20).

Tes tertulis bisa digunakan tetapi perlu dilengkapi dengan penggunaan alat ukur yang dapat mengungkap kemampuan siswa dari aspek kerja ilmiah (keterampilan dan sikap ilmiah) dan sejauh mana siswa dapat menerapkan informasi pengetahuan yang diperolehnya. Alat penilaian yang diasumsikan dapat memenuhi hal tersebut antara lain tes kinerja atau performance test dan jenis alternatif lainnya seperti penilaian produk, portofolio, penilaian projek, penilaian sikap, penilaian diri dan penilaian tingkah laku (Stiggins, 1994: p. 159).

Penggunaan model penilaian otentik dalam pendidikan agama Buddha masih jarang dilakukan. Beberapa guru pendidikan agama Buddha masih berorientasi pada materi dan hasil belajar, bukan dari proses pembelajaran. Penilaian proses pembelajaran pendidikan agama Buddha harus tercermin dalam ranah kognitif, afektif, dan psikomotor. Hal tersebut diharapkan dapat menilai secara menyeluruh keberhasilan siswa dalam pembelajaran.
Pengembangan Model Asesmen Otentik (MAO) dalam pembelajaran merupakan salah satu kompetensi guru pendidikan agama Buddha yang perlu dikembangkan secara berkelanjutan. Pengembangan MAO ini juga untuk melihat perkembangan belajar siswa dalam pembelajaran pendidikan agama Buddha. Oleh karena itu, sangat penting melakukan penelitian berkaitan dengan asesmen otentik dalam pembelajaran pendidikan agama Buddha di SD.

Penelitian ini bertujuan:

Mengembangkan sebuah produk berupa Model Asesmen Otentik pada pembelajaran pendidikan agama Buddha kelas IV, V dan VI SD yang memenuhi persyaratan asesmen yang baik dan lengkap dengan pedoman pemakaiannya; 2) Mendeskripsikan prosedur pengembangan Model Asesmen Otentik pada pembelajaran pendidikan agama Buddha sebagai laporan informatif; dan 3) Mendeskripsikan karakteristik Model Asesmen Otentik pada pembelajaran pendidikan agama Buddha sebagai laporan informatif.

\section{PEMBAHASAN \\ Model Asesmen Otentik}

Istilah asesmen otentik pertama kali diperkenalkan oleh Grant P Wiggins pada tahun 1988 dalam jurnal Phi Delta Kappan yang berjudul Authentic assessment. Sejak itulah para ahli dan praktisi pendidikan mulai ramai membicarakan tentang alternatif baru dalam pengukuran hasil belajar. Penilaian otentik mementingkan penilaian proses dan hasil sekaligus. Dengan demikian seluruh tampilan siswa dalam rangkaian kegiatan pembelajaran dapat dinilai secara objektif, apa adanya, dan tidak semata-mata hanya berdasarkan hasil akhir (produk) saja. Selain itu amat banyak kinerja siswa yang ditampilkan selama berlangsungnya kegiatan pembelajaran sehingga penilaiannya haruslah dilakukan selama dan sejalan dengan berlangsungnya kegiatan proses pembelajaran. Jika dilihat dari sudut pandang teori Bloom sebuah model yang dijadikan acuan pengembangan penilaian dalam beberapa kurikulum di Indonesia sebelum ini penilaian haruslah mencakup ranah kognitif, afektif, dan psikomotorik.

Cara penilaian juga bermacam-macam, dapat menggunakan model nontes dan tes sekaligus, serta dapat dilakukan kapan saja bersamaan dengan kegiatan pembelajaran. 
Namun, semuanya harus tetap terencana secara baik. Misalnya, dengan memberikan tes (ulangan) harian, latihan-latihan di kelas, penugasan, wawancara, pengamatan, angket, catatan lapangan/harian, portofolio, dan lainlain. Penilaian yang dilakukan lewat berbagai cara atau model, menyangkut berbagai ranah, serta meliputi proses dan produk inilah yang kemudian disebut sebagai penilaian otentik. Otentik dapat berarti dan sekaligus menjamin: objektif, nyata, konkret, benar-benar hasil tampilan siswa, serta akurat dan bermakna.

Arends (1997: p. 284) menafsirkan asesmen otentik sebagai proses penilaian kemampuan siswa dalam melaksanakan tugastugas tertentu dalam situasi nyata. Magdeleine \& Henk G Schmidt (2007) juga menegaskan bahwa asesmen otentik mencari dan mengumpulkan serta mensintesis informasi kemampuan siswa dalam memahami dan menerapkan pengetahuan dan keterampilan proses dalam situasi nyata. Grant Wiggins menekankan perlunya kinerja ditampilkan secara efektif dan kreatif. Tugas yang diberikan dapat berupa pengulangan tugas atau masalah yang analog dengan masalah dihadapi orang dewasa (warga negara, konsumen, profesional) di bidangnya. Biasanya suatu asesmen otentik melibatkan suatu tugas bagi para siswa untuk menampilkan, dan sebuah kriteria penilaian atau rubrik yang akan digunakan untuk menilai penampilan berdasarkan tugas tersebut.

Kegiatan penilaian tidak sekedar menanyakan atau menyadap pengetahuan yang telah diketahui pembelajar, melainkan kinerja secara nyata dari pengetahuan yang telah dikuasai. Sebagaimana dinyatakan Mueller (2008) penilaian otentik merupakan: "a form of assessment inwhich students are asked to perform real-world tasks that demonstrate meaningful application of essential knowledge and skills". Artinya bentuk penilaian dilakukan dimana siswa diminta untuk melakukan tugastugas dunia nyata yang menunjukkan kebermaknaan dari penerapan pengetahuan dan keterampilan. Hampir sama dengan pernyataan Mueller, selanjutya Stiggins (dalam Mueller, 2008) mengungkapkan bahwa penilaian otentik merupakan penilaian kinerja (perfomansi) yang meminta pembelajar untuk mendemonstrasikan ketrampilan dan kompetensi tertentu yang merupakan penerapan pengetahuan yang dikuasainya.

Hal serupa dikemukakan oleh Hiebert, Valencia, \& Afferbach (1994, http://www.eduplace.com/, diunduh 5-9-2013) menyatakan bahwa penilaian otentik merupakan penilaian terhadap tugas-tugas yang menyerupai kegiatan membaca dan menulis sebagaimana halnya di dunia nyata dan di sekolah. Tujuan penilaian itu adalah untuk mengukur berbagai keterampilan dalam berbagai konteks yang mencerminkan situasi di dunia nyata dimana keterampilan-keterampilan tersebut digunakan. Dalam pendidikan agama Buddha misalnya siswa dituntut untuk melakukan praktek ritual Buddhis berdasarkan materi yang telah mereka dapatkan dari guru agama Buddha di sekolah.

Asesmen otentik dalam pembelajaran adalah suatu proses atau upaya formal pengumpulan informasi yang berkaitan dengan variabel-variabel penting pembelajaran sebagai bahan evaluasi dan pengambilan keputusan oleh guru untuk memperbaiki proses dan hasil belajar siswa (Herman et al, 1992 : p. 95; Popham, 1995 : p. 3). Variabel-variabel penting yang dimaksud sekurang-kurangnya meliputi pengetahuan, pemahaman, keterampilan dan sikap siswa dalam pembelajaran yang diperoleh oleh guru dengan berbagai metode dan prosedur baik formal maupun informal. Dari beberapa pendapat tersebut didapat pemahaman bahwa asesmen otentik adalah proses asesmen yang dilakukan secara menyeluruh (meliputi semua aspek pembelajaran), berkelanjutan, dan tidak terpisahkan dari proses pembelajaran yang bertujuan untuk mengetahui hasil belajar siswa, memperbaiki proses belajar, dan sebagai belajar siswa itu sendiri.

Tugas otentik atau authentic tasks: is an assignment given to students designed to assess their ability to apply standard-driven knowledge and skills to real-world challenges. Dengan kata lain, suatu tugas yang meminta siswa melakukan atau menampilkannya dianggap otentik apabila: (i) siswa diminta untuk mengkonstruk respons mereka sendiri, bukan sekedar memilih dari yang tersedia; (ii) tugas merupakan tantangan yang mirip (serupa) yang dihadapkan dalam (dunia) kenyataan sesungguhnya.

Baron's (Marzano, 1993) mengemukakan lima kriteria task untuk penilaian otentik, yaitu: 1) tugas tersebut bermakna baik bagi siswa maupun bagi guru; 2) tugas disusun bersama atau melibatkan siswa; 3) tugas tersebut menuntut siswa menemukan dan menganalisis informasi sama baiknya dengan menarik kesimpulan tentang hal tersebut; 4) 
tugas tersebut meminta siswa untuk mengkomunikasikan hasil dengan jelas; 5) tugas tersebut mengharuskan siswa untuk bekerja atau melakukan. Anonymous (2005) mengemukakan dua hal yang perlu dipilih dalam menyiapkan tugas dalam penilaian otentik, yaitu keterampilan (skills) dan kemampuan (cabilities).

Anonymous mengungkapkan lima dimensi yang perlu dipertimbangkan pada saat menyiapkan task yang otentik pada pembelajaran sains. Pertama, length atau lama waktu pengerjaan tugas. Kedua, jumlah tugas terstruktur yang perlu dilalui siswa. Ketiga, partisipasi individu, kelompok atau kombinasi keduanya. Keempat, fokus evaluasi: pada produk atau pada proses. Kelima, keragaman cara-cara komunikatif yang dapat digunakan siswa untuk menunjukkan kinerjanya.

Penilaian otentik merupakan penilaian langsung dan ukuran langsung (Mueller, 2006: p. 1) saat melakukan penilaian akan lebih baik jika penilaian dilaksanakan saat kegiatan itu berlangsung, contohnya kemampuan berpendapat, saat berdiskusi. Begitu pula menilai sikap atau perilaku terhadap sesuatu atau pada saat melakukan sesuatu. Dalam konteks pendidikan agama Buddha misalnya pada saat mendapatkan materi praktek memberikan ceramah Dhamma (Dhamadesana) ataupun praktek perbuatan baik atau kemoralan.

Azmawi Zainul (2001: p. 7-8) menegaskan perlunya asesmen alternatif untuk mengukur kemampuan siswa diluar kemampuan kognitif. Menurut Howard Gardner ada tujuh macam kemampuan dasar, yaitu visual-spatial, bodily-kinesthetic, musicalrhytmical, enterpersonal, intrapersonal, logical mathematical, dan verbal linguistic. Dalam pendidikan agama Buddha kemampuan interpersonal dan intrapersonal adalah yang paling menonjol untuk dinilai. Oleh karena kemampuan intrapersonal melibatkan banyak aspek maka asesmen otentik sangat diperlukan dalam pembelajaran agama Buddha.

Landasan psikologis pelaksanaan asesmen otentik diantaranya teori belajar dari Shapiro (1990) tentang teori fleksibilitas kognitif. Teori ini menjelaskan bahwa belajar menghasilkan kemampuan secara spontan untuk merespon segala perubahan yang terjadi secara terus menerus dan seketika. Teori ini menkankan bahwa belajar tidak pernah berhenti karena situasi didunia nyata juga terus berubah.
Pada teori ini penilaian dilakukan pada konteks belajar dan tidak terpisah dari situasi yang dihadapi. Asesmen otentik merupakan asesmen yang menyentuh seluruh aspek pembelajaran.

Penyelenggaraan penilaian jenis apa pun menuntut adanya kegiatan siswa dalam menyelesaikan tugas-tugas secara jelas. Menurut Marc Tucker (dalam Mar-zano, 1993:p. 15), guru tidak dapat menilai kinerja siswa tanpa memberikan tugas-tugas kepada siswa; begitu juga guru tidak dapat menilai tingkat prestasi siswa tanpa adanya bukti otentik adanya tugas-tugas yang dikerjakan siswa secara nyata. Dengan demikian apabila asesmen kinerja diterapkan guru, maka dengan sendirinya siswa mendapat kesempatan untuk mengungkapkan pengetahuan sebelumnya, menunjukkan penguasaan terhadap pengetahuan dan keterampilan baru dalam memecahkan persoalan yang dihadapinya. Tugas-tugas kinerja dalam pengajaran pendidikan agama Buddha di Sekolah Dasar hendaknya dipilih atau diciptakan secara menarik dan disesuaikan dengan tujuan pembelajaran dan tingkat perkembangan siswa. Hal demikian diduga dapat meningkatkan motivasi siswa untuk terlibat secara aktif dalam kegiatan pembelajaran yang memiliki kadar ontask, hands-on, dan minds-on yang relatif tinggi.

Dalam menerapkan penilaian terhadap kinerja siswa perlu diperhatikan empat komponen berikut ini: (1) tugas-tugas menghendaki siswa menggunakan pengetahuan dan proses yang telah mereka pelajari; (2) ceklis yang mengidentifikasi aspek-aspek yang diamati; (3) seperangkat deskripsi dari suatu proses yang digunakan sebagai dasar untuk menilai keseluruhan kinerja; (4) contoh-contoh dengan mutu yang baik sebagai model dari pekerjaan yang harus dikerjakan siswa (Moh. Nur, 1997: 2). Dengan demikian, guru dalam memberikan tugas kepada siswa hendaknya didasarkan pada materi apa yang sudah disampaikan dan atau akan dipelajari oleh siswa, sehingga ada kesesuaian dengan kompetensi yang akan dicapai. Selanjutnya penilaian kerja tersebut disertai dengan aspekaspek apa saja yang akan diamati sehingga dalam melakukan penilaian akan terperinci. Deskripsi tentang penilaian yang dilakukan juga diperlukan, hal ini sebagai bahan awal dalam memperlihatkan sejauh mana penilaian yang akan dilakukan dan sesuai tidak dengan 
tujuannya. Kemudian bentuk penilaian kinerja tersebut hendaknya diberikan contoh agar memberi kemudahan kepada siswa untuk mengerjakan tugas tersebut.

Asesmen otentik dalam proses pembelajaran adalah proses pengumpulan informasi oleh guru tentang perkembangan dan pencapaian pembelajaran yang dilakukan siswa melalui berbagai teknik sehingga mampu mengungkapkan sejauh mana kemampuan siswa dalam menguasai materi. Beberapa kritik menyarankan agar digunakan cara yang terfokus pada performa aktual siswa atau tugas kehidupan nyata melalui asesmen otentik. Asesmen otentik merupakan metode yang digunakan untuk memperoleh informasi tentang kemampuan siswa dalam konteks yang merefleksikan kehidupan nyata.

Asesmen otentik tidak hanya mengacu pada penguasaan satu bidang tertentu saja, melainkan menyeluruh dan mencakup aspek kognitif, afektif dan psikomotorik. Hal ini sesuai dengan pendapat yang dikemukakan oleh Colin (1991: p. 3). "assesment as a general term enhancing all methods customarily to appraise performance of individual pupil or a group. It may refer to abroad apprasial including many sources of evidence and many aspects of a pupil's knowledge, understanding, skill and attitudes." Berdasarkan kutipan tersebut, penilaian merupakan salah satu cara untuk memberitahukan peningkatan kinerja murid secara individual maupun kelompok. Banyak bukti sebagai bahan rujukan pada sistem pemberitahuan di luar negeri yang melakukan penilaian dari banyak aspek yaitu pengetahuan, pemahaman, keterampilan dan sikap.

Menurut Pedoman Asesmen untuk Sekolah Dasar (Depdiknas, 2006 : p. 1) asesmen merupakan bagian yang tidak dapat dipisahkan dari tujuan pendidikan dasar maupun penyelenggaraan kegiatan belajar mengajar. Tujuan merupakan landasan awal yang digunakan sebagai pedoman dalam penyelenggaraan kegiatan belajar mengajar dan asesmen adalah alat yang digunakan untuk meraih tujuan yang diharapkan. Oleh karena itu melalui asesmen maka tercapai atau tidak tujuan pendidikan yang diharapkan itu dapat diketahui baik itu pada proses maupun hasilnya.

Menurut Zainul (2001: p. 23), ada beberapa jenis tugas yang dapat dilakukan dalam asesmen otentik, tugas-tugas tersebut adalah ; 1) Computer adaptif testing, 2) tes pilihan ganda diperluas dengan memberikan alasan terhadap jawaban yang dipilih, 3) Extended respons atau open ended question, 4) group performance assessment atau individual performance, 5) interview, 6) observasi partisipatif, 7) portofolio sebagai kumpulan hasil karya siswa, 8) proyek, expo atau demonstrasi, 9) constructed respons. Dengan demikian banyak model tugas yang bisa digunakan dalam pengembangan asesmen otentik. Model tugas tersebut telah mengalami perkembangan dari model tugas-tugas asesmen pada umumnya. Misalnya bentuk pilihan ganda masih bisa digunakan namun ada pengembangan yaitu siswa harus memberikan alasan terhadap jawaban yang dipilihnya.

\section{Model Pembelajaran Pendidikan Agama Buddha}

Pembelajaran pendidikan Agama Buddha merupakan salah satu mata pelajaran yang diajarkan kepada siswa Sekolah Dasar beragama Buddha. Proses pembelajaran pendidikan agama Buddha bertujuan menambah wawasan dan pengetahuan tentang agama Buddha serta membentuk kemoralan yang baik bagi anak. Dalam proses tranformasi pengetahuan ini tidak dapat dipindahkan begitu saja dari pikiran seseorang dalam hal ini guru, ke kepala orang lain dalam hal ini siswa. Siswa harus mampu mengartikan sendiri apa yang sudah diajarkan oleh guru dan menyesuaikan dengan apa yang pernah mereka alami (Lorsbach \& Tobin, 1992 dalam Suparno 1997: p. 19).

Pembelajaran pendidikan agama Buddha bukan hanya sekedar menghafal serta mampu menyelesaikan setiap tugas dan ujian yang diberikan oleh guru, tetapi juga bagaimana para siswa mamapu mengaplikasikan apa yang mereka dapatkan dari guru pada kehidupan sehari-hari. Pembelajaran pendidikan agama Buddha di sekolah hendaknya menggunakan variasi dalam model pembelajarannya sehingga tidak terjadi kebosanan pada siswa dan akan mendukung maksimalnya proses pembelajaran maupun hasilnya. Sedangkan model-model yang bisa diterapkan dalam pembelajaran pendidikan agama Buddha antara lain Model Pembelajaran Alternatif, Model Classroom Meeting, Model Cooperative Learning, Model Integrated Learning, Model Inquiry Learning, dan Model Quantum Learning.

Tujuan umum pendidikan tidak berbeda dengan tujuan pembabaran Dhamma yang 
diamanatkan oleh Sang Buddha, mereka mengemban misi atas dasar cinta kasih demi kebaikan, kesejahteraan, keselamatan, dan kebahagiaan bagi orang banyak, seperti yang tercantum dibait keempat Mahamanggala Sutta kitab suci Khuddhakapatha,Khuddaka Nikaya yaitu memiliki pengetahuan dan ketrampilan, terlatih baik dalam tata susila, ramah tamah dalam ucapan, itulah berkah utama. Bahusaccanca secara umum berarti memiliki pengetahuan yang luas atau banyak mendengar. Pada zaman Sang Buddha pendidikan dilakukan secara lisan dari generasi ke generasi berikutnya, karena pendidikan dan pengetahuan tertulis pada waktu itu belum dilakukan. Tingkat pengetahuan orang terpelajar ditentukan dari daya ingat setelah mendengarkan pembicaraan orang lain. Seorang siswa harus mempunyai kualitas seperti daya ingat yang kuat, keinginan belajar dan bergaul dengan orang terpelajar, seseorang yang banyak mendengar dan mengingatnya (bahussuta) adalah orang yang banyak memiliki pengetahuan. Hal ini merupakan berkah utama baik digunakan untuk melaksanakan Dhamma maupun pengendalian diri melalui sila yang dilaksanakan sehari-hari (Rashid, 1997: p. 72).

Belajar merupakan bentuk pengembangan pola pikiran manusia untuk perubahan tingkah laku, baik perubahan positif manpun negatif. Pikiran manusia sangat mendominan akan perkembangan kemampuan manusia baik aspek kognitif, afektif maupun psikomotor. Seperti yang dikhotbahkan Sang Buddha dalam Dhammapada syair I dan 2 yang berbunyi sebagai berikut:

Pikiran adalah pelopor dari segala sesuatu, pikiran adalah pemimpin, pikiran adalah pembentuk. Bila seseorang berbicara atau berbuat dengan pikiran jahat, maka penderitaan akan mengikutinya bagaikan roda pedati mengikuti langkah lembu yang menariknya.

Pikiran adalah pelopor dari segala sesuatu, pikiran adalah pemimpin, pikiran adalah pembentuk. Bila seseorang berbicara atau berbuat dengan pikiran murni, maka kebahagiaan akan mengikutinya bagaikan bayang-bayang yang tak pernah meninggalkan bendanya (Dhammapada syair 1 dan 2)
Berdasarkan kutipan Dhammapada tersebut, dapat dipahami bahwa segala perbuatan yang muncul baik melalui ucapan, pikiran dan badan jasmani berawal dari pikiran. Apabila pikiran dikondisikan baik, maka perbuatan yang muncul akan baik. Tetapi sebaliknya apabila pikiran dikondisikan tidak baik, maka perbuatan yang muncul adalah tidak baik pula.

Keberhasilan belajar tergantung dari tingkat kemampuan siswa dalam menangkap dan menerima materi pelajaran yang diberikan guru melalui proses belajar mengajar, kategori tingkat kemampuan anak ada yang cerdas, sedang dan kurang. Bagi anak yang cerdas akan lebih banyak kesempatan untuk lulus dalam menghadapi berbagai evaluasi. Belajar di sekolah memiliki banyak manfaat bagi perkembangan ilmu, moral dan keterampilan. Mata pelajaran tentang ilmu, moral dan keterampilan saling mempengaruhi satu sama lainnya. Ketiga jenis pengetahuan ini jika digabungkan menjadi satu akan menjadi pengetahuan yang sejati. Seperti yang dijelaskan dalam Khandavagga, Samyutta Nikaya tentang pengetahuan sejati yaitu pengetahuan yang dimiliki oleh siswa mulia terpelajar memahami bentuk asal mulanya, berhentinya dan jalan menuju berhentinya. Dia memahami perasaan, persepsi, bentukanbentukan berkehendak, kesadaran, asal mulanya serta mengetahui jalan menuju terhentinya (Jotidhammo, 2010: p. 1754).

Khotbah Sang Buddha yang tertuang dalam Dighanakha Sutta, Paribbajaka Vagga, Majjhima Nikaya berisi tentang penghapusan pandangan pandangan salah yang ditujukan kepada Dighanakha seorang petapa kelana keponakan Bhante Sariputta. Ketika khotbah dibabarkan Bante Sariputta ikut mendengarkan bagaikan diberi makanan yang sebenarnya disiapkan untuk orang lain. Beliau langsung maju pesat dari tingkat Sotapana menuju tingkat Arahat dengan pengetahuan analitis berunsur empat (Patisambada Nana). Keempat unsur tersebut antara lain:

a. Memahami maksud dan tujuan, mampu menjelaskan atau menjabarkan secara rinci, dan mampu mempertimbangkan akibat.

b. Memahami intisari atau mampu meringkas dan meneliti atau menunjukkan penyebab. 
c. Cakap memilih kata atau menggunakan bahasa yang tepat, yang mudah dimengerti dengan benar.

d. Kelancaran dalam cara penerapan atau penyesuaian dan dengan bijaksana mampu menguasai persoalan yang timbul mendadak.

Pada akhir khotbah petapa kelana Dighanakha mencapai tingkat kesucian tahap awal yaitu Sotapana. Bhante Sariputta mengalami perkembangan spiritual dengan pencapaian tingkat-tingkat kesucian dengan usaha menjalankan Dhamma dengan baik, begitu juga dengan keberhasilan belajar. Belajar harus berusaha dengan sekuat tenaga guna meningkatkan kemampuan kognitif, afektif dan psikomotor (Anggawati, 2000: p. 101). Guru dalam proses kegiatan belajar mengajar sangat berperan dalam berhasil tidaknya mencapai tujuan pendidikan yang telah ditetapkan oleh pemerintah. Tingkat keberhasilan belajar dapat dilihat melalui berbagi bentuk evaluasi baik tes lisan maupun tertulis, yang dapat ditukar dengan nilai.

\section{METODE PENELITIAN}

Tujuan penelitian ini adalah untuk mengembangkan MAO dalam pembelajaran pendidikan agama Buddha, yang memenuhi kriteria asesmen yang berkualitas. MAO yang dikembangkan merupakan model assessment for learning, yakni di laksanakan dalam proses pembelajaran. Berdasarkan penelitian tersebut, peneliti menggunakan model penelitian dan pengembangan pembelajaran, bukan pengembangan model pengukuran.

Penyusunan MAO meliputi penyusunan model, validasi pakar, dan melatih guru. Model yang dimaksud terdiri atas instrumen: Rencana Pelaksanaan Pembelajaran (RPP), lembar tugas siswa, lembar pengamatan ilmiah untuk kelas IV, V, dan VI, asesmen unjuk kerja untuk kelas IV, V, dan VI, lembar pengamatan ketrampilan proses pendidikan agama Buddha untuk kelas IV, V, dan VI, lembar pengamatan aktifitas guru dalam kelas, angket efektifitas MAO, dan pedoman penskoran untuk setiap instrumen dan buku panduan penggunaan MAO dalam kelas. Sedangkan validasi pakar dilakukan terhadap angket penelitian.

Analisis data yang digunakan dalam penelitian awal adalah pendekatan deskriptif disertai dengan narasi yang sesuai dengan kepentingan penelitian, sedangkan analisis pada saat pengembangan model adalah pendekatan kualitatif dan kuantitatif. Penilaian dilakukan dengan cara memberikan angka antara 1 sampai 4.

$$
\begin{aligned}
& \quad \mathrm{V}=\sum s /[\mathrm{r}(c-\mathrm{lo})] \\
& \text { Keterangan: } \\
& \mathrm{V} \quad \text { :Validitas isi } \\
& \text { 1o : Angka penilaian validitas yang terendah (1) } \\
& \mathrm{c}: \text { Angka penilaian validitas yang tertinggi (4) } \\
& \mathrm{r}: \text { Angka yang diberikan oleh seorang penilai } \\
& s=\text { r-lo }
\end{aligned}
$$

\section{DATA HASIL STUDI AWAL}

Studi pendahuluan dilakukan terhadap keadaan sekolah, kondisi pembelajaran dan asessmen lapangan, dilakukan dengan observasi proses pembelajaran di kelas, wawancara, dan kuesioner dengan guru-guru pendidikan agama Buddha di Kabupaten Wonogiri. Berdasarkan hasil observasi proses pembelajaran pendidikan agama Buddha di beberapa Sekolah Dasar diperoleh data bahwa kondisi pelaksanaan proses pembelajaran pendidikan agama Buddha di Sekolah Dasar dilakukan dengan pendekatan yang konvensional, komunikasi yang terjadi dominan satu arah dari guru, RPP yang dibuat belum menjadi acuan dalam pelaksanaan pembelajaran, dan dalam melakukan penilaian hasil belajar dominan aspek kognitif dengan tes tertulis serta hanya sebagian kecil guru yang melaksanakan penilaian dalam proses pembelajaran.

Berdasarkan hasil wawancara terhadap beberapa guru pendidikan agama Buddha di Kabupaten Wonogiri diperoleh data bahwa, (1) persepsi guru terhadap pembelajaran pendidikan agama Buddha sangat baik dan guru mempunyai motivasi yang tinggi untuk melakukan inovasi terhadap pelaksanaan pembelajaran pendidikan agama Buddha dan assesmennya, (2) minat belajar siswa cukup tinggi terutama yang dilakukan dengan kegiatan yang menggunakan alat bantu bersifat konkret yang ada di lingkungan siswa.

Data hasil penyebaran angket terhadap pelaksanan pembelajaran dan penilaian memperlihatkan bahwa assesmen yang dilakukan disekolah ternyata belum sesuai dengan sistem asesmen dalam Kurikulum Tingkat Satuan Pendidikan (KTSP). Kinerja siswa maupun penilaian diri oleh siswa tidak pernah dilakukan oleh guru. Padahal, kurikulum KTSP untuk mata pelajaran pendidikan agama Buddha menuntut agar penilaian kinerja khususnya dalam pelaksanaan pembelajaran wajib dilaksanakan. Tanpa itu, sulit bagi guru untuk memberikan nilai kompetensi dasar. Hal 
ini juga memperlihatkan bahwa metode mengajar yang digunakan masih didominasi dengan metode ceramah, tanya jawab, dan latihan soal, sedangkan metode demonstrasi, praktik, mendapat porsi yang masih minim. Hasil ini dijadikan rujukan untuk mengembangkan model asessmen otentik dalam pembelajaran pendidikan agama Buddha, terutama di Sekolah Dasar.

\section{ANALISIS DATA UJI COBA}

\section{Hasil validasi angket efektifitas MAO dalam satu Kabupaten}

Kriteria penilaian dalam validasi efektifitas MAO dengan menggunakan pemberian angka 1 sampai dengan 4. Angka 1 menunjukkan kriteria kurang baik, angka 2 menunjukkan kriteria cukup baik, angka 3 menunjukkan kriteria baik dan angka 4 menunjukkan kriteria sangat baik. Hasil penilaian efektifitas MAO pra uji coba terbatas sebagai berikut:

Tabel Hasil penilaian efektifitas MAO pra uji coba terbatas

\begin{tabular}{|l|c|l|}
\hline $\begin{array}{c}\text { Aspek yang } \\
\text { dinilai }\end{array}$ & $\begin{array}{c}\text { Rata-rata hasil } \\
\text { penilaian }\end{array}$ & Keterangan \\
\hline Validitas & 3,78 & Valid \\
\hline Reliabilitas & 3,67 & Reliabel \\
\hline Objektif & 3,83 & Sangat objektif \\
\hline Sistematis & 3,56 & Sistematis \\
\hline Praktis & 3,92 & Praktis \\
\hline Keseluruhan & $\mathbf{3 , 7 5}$ & Efektif \\
\hline
\end{tabular}

Tabel di atas hasil penilaian efektifitas MAO pra uji coba terbatas. Terdapat enam aspek yang diuji yaitu validitas, reliabilitas, objektif, sistematis, dan praktis. Rata-rata menunjukkan nilai baik. Sedangkan hasil penilaian efektifitas MAO setelah uji coba terbatas sebagai berikut:

Tabel 1. hasil penilaian efektifitas MAO setelah uji coba terbatas

\begin{tabular}{|l|c|l|}
\hline $\begin{array}{c}\text { Aspek yang } \\
\text { dinilai }\end{array}$ & $\begin{array}{c}\text { Rata-rata } \\
\text { hasil } \\
\text { penilaian }\end{array}$ & Keterangan \\
\hline Validitas & 3,89 & Valid \\
\hline Reliabilitas & 3,89 & Reliabel \\
\hline Objektif & 3,83 & Sangat objektif \\
\hline Sistematis & 4 & Sistematis \\
\hline Praktis & 3,92 & Praktis \\
\hline Keseluruhan & $\mathbf{3 , 9 2}$ & Efektif \\
\hline
\end{tabular}

Hasil validasi angket efektifitas MAO secara keseluruhan setelah uji coba mengalami peningkatan dibanding pra uji coba. Rata-rata hasil penilaian secara keseluruhan pra uji coba sebesar 3,75 dan setelah uji coba meningkat menjadi 3,92. Aspek validitas, reliabilitas, dan sistematis juga mengalami peningkatan, sedangkan aspek objektifitas dan praktis rata-rata hasil penilaiannya tidak mengalami perubahan.

Rata-rata hasil penilaian aspek validitas pra uji coba sebesar 3,78 dan setelah uji coba meningkat menjadi 3,89, aspek reliabilitas juga meningkat dari 3,67 menjadi 3,89 dan aspek sistematis meningkat dari 3,56 menjadi 4. Sedangkan aspek objektifitas tidak mengalami perubahan dengan rata-rata hasil penilaian sebesar 3,83 dan aspek praktis juga mempunyai rata-rata tetap yaitu sebesar 3,92.

\section{Hasil Validasi RPP Satu Kabupaten}

Hasil validasi RPP Pendidikan Agama Buddha materi Sila dilakukan oleh 3 guru pendidikan agama Buddha Kabupaten Wonogiri menggunakan kriteria penilaian validasi: sangat kurang, kurang, baik, sangat baik. seperti pada lampiran 5. Mencermati tabel tersebut tampak bahwa pada tahap uji coba ini penilai pada umumnya memberikan penilaian yang baik pada semua aspek yang dinilai, sehingga perlu adanya sedikit revisi, yang akan digunakan pada uji coba yang selanjutnya yaitu uji coba satu karesidenan Surakarta.

Tabel Hasil validasi RPP

\begin{tabular}{|c|c|c|c|c|c|}
\hline \multirow{3}{*}{$\begin{array}{l}\mathrm{N} \\
\mathrm{O}\end{array}$} & \multirow{3}{*}{$\begin{array}{l}\text { Aspek yang } \\
\text { dinilai }\end{array}$} & \multicolumn{4}{|c|}{ Hasil Validasi } \\
\hline & & \multicolumn{2}{|c|}{ Pra uji coba } & \multicolumn{2}{|c|}{ Setelah uji coba } \\
\hline & & $\begin{array}{l}\text { Rata- } \\
\text { rata } \\
\text { penilai } \\
\text { an }\end{array}$ & $\begin{array}{l}\text { keter } \\
\text { anga } \\
n\end{array}$ & $\begin{array}{l}\text { Rata- } \\
\text { rata } \\
\text { penilai } \\
\text { an }\end{array}$ & $\begin{array}{l}\text { Ketera } \\
\text { ngan }\end{array}$ \\
\hline 1 & $\begin{array}{l}\text { Cakupan } \\
\text { RPP }\end{array}$ & 3,5 & Baik & 3,78 & $\begin{array}{l}\text { Sangat } \\
\text { baik }\end{array}$ \\
\hline 2 & Bahasa & 3,75 & Baik & 3,89 & $\begin{array}{l}\text { Sangat } \\
\text { baik }\end{array}$ \\
\hline 3 & $\begin{array}{l}\text { Penilaian } \\
\text { Umum }\end{array}$ & $B$ & & $A$ & \\
\hline & $\begin{array}{r}\text { Keterangan: } \\
\mathrm{A}=\text { dapa } \\
\mathrm{B}=\text { dapa } \\
\mathrm{C}=\text { dapa } \\
\mathrm{D}=\text { belu }\end{array}$ & ligunal & dengar & $\begin{array}{l}\text { visi } \\
\text { edikit } \\
\text { anyak }\end{array}$ & \\
\hline
\end{tabular}


Data hasil validasi RPP oleh pakar sebelum dan sesudah uji caba terbatas mengalami kenaikan. Dimana Aspek petunjuk cakupan RPP dalam pra uji coba mempunyai rata-rata penilaian 3,5 , sedangkan setelah uji coba mengalami kenaikan sebesar 0,28 menjadi 3,78. Sehingga aspek petujuk cakupan RPP dari baik menjadi sangat baik. Aspek Bahasa juga mengalami kenaikan sebelum dan sesudah uji coba, kenaikan tersebut sebesar 0,14 . Dimana besarnya nilai sebelum uji coba adalah 3,75, sedangkan setelah uji coba menjadi 3.89 .

\section{Hasil validasi angket MAO oleh pakar dalam satu Kabupaten}

Tabel Hasil validasi angket MAO

\begin{tabular}{|c|c|c|c|c|c|}
\hline \multirow{3}{*}{$\begin{array}{l}\mathrm{N} \\
\mathrm{O}\end{array}$} & \multirow{3}{*}{$\begin{array}{l}\text { Aspek } \\
\text { yang } \\
\text { dinilai }\end{array}$} & \multicolumn{4}{|c|}{ Hasil Validasi } \\
\hline & & \multicolumn{2}{|c|}{ Pra uji coba } & \multicolumn{2}{|c|}{ Setelah uji coba } \\
\hline & & $\begin{array}{l}\text { Rata- } \\
\text { rata } \\
\text { penilai } \\
\text { an }\end{array}$ & $\begin{array}{l}\text { keter } \\
\text { anga } \\
\mathrm{n}\end{array}$ & $\begin{array}{l}\text { Rata- } \\
\text { rata } \\
\text { penilai } \\
\text { an }\end{array}$ & Keterangan \\
\hline 1 & Petunjuk & 3,67 & Baik & 3,84 & Sangat baik \\
\hline 2 & Cakupan & 3,73 & Baik & 3,87 & Sangat baik \\
\hline 3 & Bahasa & 3,78 & Baik & 3,89 & Sangat baik \\
\hline 3 & $\begin{array}{l}\text { Penilaian } \\
\text { Umum }\end{array}$ & B & & A & \\
\hline & $\begin{array}{l}\text { Kete } \\
\mathrm{A}=\mathrm{da} \\
\mathrm{B}=\mathrm{da} \\
\mathrm{C}=\mathrm{da} \\
\mathrm{D}=\mathrm{be}\end{array}$ & $\begin{array}{l}\text { ngan Tab } \\
\text { at diguna } \\
\text { at digunal } \\
\text { at digunal } \\
\text { m dapat }\end{array}$ & $\begin{array}{l}\text { l: } \\
\text { an tan } \\
\text { an den } \\
\text { an den } \\
\text { igunak }\end{array}$ & $\begin{array}{r}\text { revisi } \\
\text { sedik } \\
\text { bany }\end{array}$ & $\begin{array}{l}\text { evisi } \\
\text { evisi }\end{array}$ \\
\hline
\end{tabular}

Data hasil angket MAO oleh pakar sebelum dan sesudah uji coba terbatas mengalami kenaikan. Dimana Aspek petunjuk angket MAO dalam pra uji coba mempunyai rata-rata penilaian 3,67 , sedangkan setelah uji coba mengalami kenaikan sebesar 0,17 menjadi 3.84 Sehingga aspek petujuk meningkat dari baik menjadi sangat baik. Aspek cakupan juga mengalami kenaikan sebelum dan sesudah uji coba, kenaikan tersebut sebesar 0,14. Dimana besarnya nilai sebelum uji coba adalah 3,73, sedangkan setelah uji coba menjadi 3.87. Aspek bahasa juga mengalami peningkatan sebesar 0,11 dimana sebelum uji coba sebesar 3,78 dan setelah uji coba menjadi 3,89.

\section{HASIL PENGAMATAN UJI COBA}

Selama pelaksanaan uji coba terbatas dan uji coba luas dalam pembelajaran di kelas, dilakukan pengamatan aktivitas guru masingmasing kelas oleh dua pengamat. Uji coba terbatas MAO dilakukan di Kabupaten Wonogiri dengan 30 objek yang terdiri dari guru pendidikan agama Buddha dan mahasiswa. Kegiatan praktek kelas masingmasing dilaksanakan 4 kali pertemuan dengan waktu dua jam pelajaran (2x35 menit).

Pengamatan keterlaksanaan MAO dalam kelas terdapat 16 aspek yang dinilai oleh pengamat dengan memberikan tanda centang (V) pada kolom ada dan tidak ada. Hasil pengamatan menunjukkan bahwa keterlaksanaan MAO uji coba terbatas lebih rendah dibandingkan dengan ujicoba luas. Beberapa faktor yang diduga menjadi penyebab kondisi tersebut adalah pembelajaran yang berbeda dari sebelumnya, sehingga membutuhkan waktu untuk penyesuaianmuatan aktivitas yang dilakukan dalam pembelajaran juga bebeda. Perasaan canggung diamati oleh pengamat, dan siswa belum siap menghadapi situasi yang baru. Berbeda dengan pengamatan keempat bahwa semua aktivitas yang telah direncanakan telah dapat direalisasikan semanya oleh guru.

Pengamatan Karakter Siswa dilakukan sebanyak 3 (tiga) kali masing-masing di tingkat Kabupaten Wonogiri dengan responden 30 siswa, di tingkat Kota Surakarta dengan responden sebanyak 55 siswa dan tingkat Provinsi Jawa Tengah 110 siswa. Pengamatan dilakukan dengan tujuan mengetahui karakterkarakter yang muncul pada diri siswa saat proses pembelajaran. Aspek-aspek yang diamati meliputi kedisiplinan, kejujuran, kemampuan kerjasama, membantu teman, menghargai pendapat teman, ketekunan, dan kehati-hatian. Skala penilaian adalah sebagai berikut:

Angka 1 artinya kurang baik

Angka 2 artinya cukup baik

Angka 3 artinya baik

Angka 4 artinya sangat baik

Skala tersebut dilengkapi dengan kriteria berdasarkan rubrik penilaian dari hasil pengamatan terhadap karakter siswa. Hasil pengamatan karakter siswa dalam tiga tahap tersebut, dapat dilihat pada tabel berikut. 
Tabel Hasil Pengamatan Karakter Siswa

\begin{tabular}{|c|l|l|l|l|}
\hline \multirow{2}{*}{$\mathrm{N}$} & \multicolumn{2}{|c|}{ Tingkat } \\
\cline { 3 - 5 } & $\begin{array}{c}\text { Aspek yang } \\
\text { diamati }\end{array}$ & $\begin{array}{c}\text { Kab. } \\
\text { Wonogiri } \\
(30 \\
\text { siswa) }\end{array}$ & $\begin{array}{c}\text { Kota } \\
\text { Surakarta } \\
(55 \text { siswa) }\end{array}$ & $\begin{array}{c}\text { Prov } \\
\text { Jateng } \\
(110 \\
\text { siswa })\end{array}$ \\
\hline 1 & Kedisiplinan & 2,97 & 3,27 & 3,5 \\
\hline 2 & Kejujuran & 2,77 & 3,16 & 3,46 \\
\hline 3 & $\begin{array}{l}\text { Kemampua } \\
\text { n kerjasama }\end{array}$ & 3,2 & 3,38 & 3,49 \\
\hline 4 & $\begin{array}{l}\text { Membantu } \\
\text { teman }\end{array}$ & 2,9 & 3,32 & 3,59 \\
\hline 5 & $\begin{array}{l}\text { Menghargai } \\
\text { pendapat } \\
\text { teman }\end{array}$ & 2,8 & 3,44 & 3,68 \\
\hline 6 & Ketekunan & 2,77 & 3,42 & 3,55 \\
\hline 7 & $\begin{array}{l}\text { Kehati- } \\
\text { hatian }\end{array}$ & 3,07 & 3,4 & 3,6 \\
\hline
\end{tabular}

Berdasarkan tabel tersebut, aspek kedisiplinan yang diamati terhadap 30 siswa di Kabupaten Wonogiri menunjukkan nilai 2,97 (dibulatkan menjadi 3) artinya rata-rata kedisiplinan siswa adalah baik yaitu siswa tidak pernah datang terlambat, menyelesaikan tugas tepat waktu, tetapi mengerjakan tugas tidak tuntas. Pada tahapan selanjutnya dengan jumlah responden sebanyak 55 siswa di tingkat Kota Surakarta, aspek kedisiplinan menunjukkan angka 3,27 artinya kedisiplinan siswa adalah baik yaitu siswa tidak pernah datang terlambat, menyelesaikan tugas tepat waktu, tetapi mengerjakan tugas tidak tuntas. Kemudian di tingkat Provinsi Jawa Tengah dengan responden sebanyak 110 siswa, pengamatan terhadap aspek kedisiplinan menunjukkan angka 3,5 artinya kedisiplinan siswa adalah baik yaitu siswa tidak pernah datang terlambat, menyelesaikan tugas tepat waktu, tetapi mengerjakan tugas tidak tuntas. Aspek kedisiplinan siswa dilihat dari tabel hasil pengamatan terhadap tiga lokasi yang berbeda menunjukkan adanya peningkatan nilai ratarata.

Hasil pengamatan terhadap aspek kejujuran yang diamati terhadap 30 siswa di Kabupaten Wonogiri menunjukkan nilai 2,77 (dibulatkan menjadi 3) artinya rata-rata kejujuran siswa adalah baik, dikatakan baik apabila siswa melaporkan hasil kinerja dan pengamatan apa adanya, tetapi siswa mencontek pekerjaan teman. Pada tahapan selanjutnya dengan jumlah responden sebanyak 55 siswa di tingkat Kota Surakarta, aspek kejujuran menunjukkan angka 3,16 artinya kejujuran siswa adalah baik, yaitu apabila siswa melaporkan hasil kinerja dan pengamatan apa adanya, tetapi masih mencontek pekerjaan teman. Kemudian di tingkat Provinsi Jawa Tengah dengan responden sebanyak 110 siswa, pengamatan terhadap aspek kejujuran menunjukkan angka 3,46 artinya kejujuran siswa adalah baik, yang artinya kejujuran siswa baik apabila mampu melaporkan hasil kinerja dan pengamatan apa adanya, dan mengakui hasil mencontek pekerjaan teman. Aspek kejujuran siswa dilihat dari tabel hasil pengamatan terhadap tiga lokasi yang berbeda menunjukkan adanya peningkatan.

Aspek kemampuan kerjasama yang diamati terhadap 30 siswa di Kabupaten Wonogiri menunjukkan nilai 3,2 artinya ratarata kemampuan kerjasama siswa adalah baik yaitu mampu bekerjasama dengan teman dalam satu kelompok dan satu kelas, mudah bergaul, tetapi tidak disenangi teman. Pada tahapan selanjutnya dengan jumlah responden sebanyak 55 siswa di tingkat Kota Surakarta, aspek kemampuan kerjasama menunjukkan angka 3,38 artinya kemampuan kerjasama siswa adalah baik, dikatakan baik jika siswa mampu bekerjasama dengan teman dalam satu kelompok dan satu kelas, mudah bergaul, tetapi tidak disenangi teman. Kemudian di tingkat Provinsi Jawa Tengah dengan responden sebanyak 110 siswa, pengamatan terhadap aspek kejujuran menunjukkan angka 3,49 artinya kemampuan siswa adalah baik, yaitu mampu bekerjasama dengan teman dalam satu kelompok dan satu kelas, mudah bergaul, tetapi tidak disenangi teman. Walaupun secara kriteria sama yakni mampu bekerjasama dengan teman dalam satu kelompok dan satu kelas, mudah bergaul, tetapi tidak disenangi teman namun aspek kemampuan kerjasama siswa jika dilihat dari nilai rata-ratanya berdasarkan tiga lokasi yang berbeda menunjukkan adanya peningkatan.

Aspek membantu teman yang diamati terhadap 30 siswa di Kabupaten Wonogiri menunjukkan nilai 2,9 artinya rata-rata kemampuan siswa dalam membantu teman adalah baik, maksudnya siswa dapat menjawab dengan sikap yang menyenangkan apabila ada teman yang bertanya, membantu teman yang kesulitan apabila diminta, tetapi tidak membantu teman kalau tidak diminta ketika melihat ada teman yang kesulitan. Pada tahapan selanjutnya dengan jumlah responden sebanyak 55 siswa di tingkat Kota Surakarta, aspek membantu siswa menunjukkan angka 3,32 artinya kemampuan siswa dalam membantu 
teman adalah baik. Kemudian di tingkat Provinsi Jawa Tengah dengan responden sebanyak 110 siswa, pengamatan terhadap aspek membantu siswa menunjukkan angka 3,59 (dibulatkan menjadi 4) artinya kemampuan siswa dalam membantu teman adalah sangat baik dengan kriteria bahwa siswa mampu menjawab dengan sikap yang menyenangkan apabila ada teman yang bertanya, membantu teman yang kesulitan apabila diminta, serta menunjukkan sikap membantu teman walaupun tidak diminta ketika ada teman yang kesulitan. Aspek membantu siswa dilihat dari tabel hasil pengamatan terhadap tiga lokasi yang berbeda menunjukkan adanya peningkatan yang berarti yaitu memiliki kesadaran untuk membantu teman tanpa diminta.

Hasil pengamatan terhadap aspek menghargai pendapat teman yang diamati terhadap 30 siswa di Kabupaten Wonogiri menunjukkan nilai 2,8 (dibulatkan menjadi 3) artinya rata-rata karakter siswa dalam menghargai pendapat teman adalah baik dengan mau mendengarkan teman yang sedang menjelaskan, mengapresiasi pendapat teman, tetapi tidak bersedia mengubah pendapat sendiri. Pada tahapan selanjutnya dengan jumlah responden sebanyak 55 siswa di tingkat Kota Surakarta, aspek menghargai pendapat teman menunjukkan angka 3,44 artinya karakter siswa dalam menghargai pendapat teman adalah baik yaitu mendengarkan teman yang sedang menjelaskan, mengapresiasi pendapat teman, tidak bersedia mengubah pendapat sendiri jika ada pendapat teman yang lebih benar. Kemudian di tingkat Provinsi Jawa Tengah dengan responden sebanyak 110 siswa, pengamatan terhadap aspek menghargai pendapat teman menunjukkan angka 3,68 (dibulatkan menjadi 4) artinya karakter siswa dalam menghargai pendapat teman adalah sangat baik yaitu mendengarkan teman yang sedang menjelaskan, mengapresiasi pendapat teman, bersedia mengubah pendapat sendiri apabila pendapat teman lebih benar dan valid. Aspek menghargai pendapat teman yang ditunjukkan siswa berdasarkan hasil pengamatan terhadap tiga lokasi yang berbeda menunjukkan adanya peningkatan.

Ketekunan siswa yang diamati terhadap 30 siswa di Kabupaten Wonogiri menunjukkan nilai 2,77 (dibulatkan menjadi 3) artinya ratarata ketekunan siswa adalah baik dengan kriteria bahwa siswa dapat menyelesaikan tugas walaupun sulit, tidak mengeluh saat mengerjakan tugas, tetapi siswa tidak bertanya pada guru ketika belum jelas. Pada tahapan selanjutnya dengan jumlah responden sebanyak 55 siswa di tingkat Kota Surakarta, aspek ketekunan siswa menunjukkan angka 3,42 artinya adalah baik yaitu mampu menyelesaikan tugas walaupun sulit, tidak mengeluh saat mengerjakan tugas, dan bersikap diam atau tidak bertanya pada guru ketika belum jelas. Kemudian di tingkat Provinsi Jawa Tengah dengan responden sebanyak 110 siswa, pengamatan terhadap aspek ketekunan siswa menunjukkan angka 3,91 (dibulatkan menjadi 4) hal ini menunjukkan ketekunan siswa meningkat menjadi sangat baik yang artinya siswa mampu menyelesaikan tugas walaupun sulit, tidak mengeluh saat mengerjakan tugas, siswa bertanya pada guru ketika belum jelas. Aspek ketekunan siswa dilihat dari tabel hasil pengamatan terhadap tiga lokasi yang berbeda menunjukkan adanya peningkatan yang berarti.

Aspek kehati-hatian yang diamati terhadap 30 siswa di Kabupaten Wonogiri menunjukkan nilai 3,07 artinya rata-rata karakter kehati-hatian siswa adalah baik maksudnya siswa mengecek alat yang akan digunakan, dan sebelum dikembalikan, mengerjakan tugas dengan hati-hati, namun tidak merapihkan kembali tempat dan alat yang digunakan selesai pembelajaran. Pada tahapan selanjutnya dengan jumlah responden sebanyak 55 siswa di tingkat Kota Surakarta, aspek kehati-hatian menunjukkan angka 3,4 artinya adalah baik, yaitu siswa mau mengecek alat yang akan digunakan, dan sebelum dikembalikan, mengerjakan tugas dengan hatihati, namun tidak merapihkan kembali tempat dan alat yang digunakan selesai pembelajaran. Kemudian di tingkat Provinsi Jawa Tengah dengan responden sebanyak 110 siswa, pengamatan terhadap aspek kehati-hatian menunjukkan angka 3,6 (dibulatkan menjadi 4) artinya kemampuan siswa adalah sangat baik dengan pengertian bahwa siswa mengecek perlengkapan yang akan digunakan, dan sebelum dikembalikan, mengerjakan tugas dengan hati-hati, serta mau merapihkan kembali tempat dan alat yang digunakan selesai pembelajaran. Aspek kehati-hatian siswa dilihat dari tabel hasil pengamatan terhadap tiga lokasi yang berbeda menunjukkan adanya peningkatan. 


\section{KESIMPULAN}

Berdasarkan tujuan dan pertanyaan serta kajian terhadap hasil dan pembahasan mengenai pengembangan model asesmen otentik dalam pembelajaran pendidikan agama Buddha, maka dapat disimpulkan sebagai berikut:

1. Persepsi guru terhadap pembelajaran agama Buddha sangat baik dan guru mempunyai motivasi yang tinggi untuk melakukan inovasi terhadap pelaksanaan pembelajaran agama Buddha dan asesmennya, dan didukung dengan minat belajar siswayang tinggi teruutama yang dilakukan dengan kegiatan yang mengggunakan alat bantu yang bersifat kongkrit yang ada di lingkunggan siswa.

2. Berdasarkan uji validitas dan reliabiitas semua instrumen MAO dalam pembelajaran pendidikan agama Buddha memiliki kriteria sebagai instrumen yang baik.

3. Berdasarkan hasil pengamatan keterlaksanaan implimentasi MAO dalam kelas di satu kabupaten, satu karesidenan dan dalam satu provinsi berhasil dengan baik dan selalu mengalami peningkatan.

\section{SARAN}

1. Bagi guru: dalam rangka meningkatkan mutu pembelajaran pendidikan agama Buddha, terutama yang berkaitan dengan asesmen, MAO dapat dijadikan salah satu model alternatif.

2. Bagi kepala sekolah: perlu mendorong dan memfasilitasi upaya pengembangan dan implikasi MAO dalam pembelajaran pendidikan agama Buddha sesuai dengan kondisi sekolah.

\section{Daftar Pus taka}

Arends, R.I. (2004). Learning to Teach. New York: McGraw-Hill Companies

Arends, R.I. (1997). Classroom intruction and management Unitedstates of American

Anonymous (2005). Performance Assessment for Science Teachers: Performance Test and Task. Available: http://www.usoe.k12.ut.us/curr/science/ perform/past5.htm
Anggawati Lanny, Cintiawati Wena. 2000. Panduan Tipitaka Kitab Suci AgamaBuddha. Klaten: Vihara Bodhivamsa.

Arikunto Suharsimi. 2009. Dasar-Dasar Evaluasi Pendidikan Jakarta: Bumi Aksara.

Azwar Saifudin. (2012). Penyusunan skalaPsikologi.

PustakaPelajar

Azmawi Zaimil, (2001). Alternative assesment. Jakarta: Dirjen Dikti.

Collin, at all. (1991). Test Equiting: Methodesnand practices, New York: Springer Verlag.

Depdiknas. (2006). Buku Dua. Pedoman Pembuatanlaporan hasil belajar,pedoman pengembangan ranah psikomotorik, pedoman pembelajarantuntas, pedoman penilaian ranah efektif, pedoman penilaian denganportofolio, pedoman manajemen pelaksanaan kurikulum berbasiskompetensi, Jakarta: Dirjen Dikdasmen.

Dahar, R.W. (1992). Dampak pertanyaan dan Teknik bertanya guru selama proses.

Desmita. 2006. Psikologi Perkembangan. Bandung: PT Remaja Rosdakarya.

Djiwandono Sri Esti Wuryani. 2006. Psikologi Pendidikan Jakarta: PT gramediaWidiasarana Indonesia

Driver. R (1982). Children's Ideas in Science. Buckingham, emgland: OpenUnivercity Press.

Halawi Leila A, McCarthy V, Pires Sandra. 2009. An Evaluation af E-Learningon the Basis of Bloom's Talcsonomy: An Exploratory Study.

Herman, J.L., dkk. (1992). A Practical Guide to alternative assesment. 
htttp://www.unesco.org/ne\#fileadmin[vIULTI MEDIA/FIO/ED/pdf/smr2012-rep ortedi.pdf diakses padatanggal 12 Agustus 2013)

htttp:// www. unesco. or/neWefa-developmentindex.pdf diakses pada tanggal 12 Agustus 2013)

Isaken, S.G., Dorval, K.B., \& Treffinger, Dj. (1994). Creative approaches toproblem solving. Dubuque. Iowa: kendall Hunt publishing companyUS Department of Education and the National School to Work Office, 2001belajar mengajar IPA pada berfikir siswa, laporan penelitian FP MIPA. IKIP Bandung.

Jotidhamma" Limiadi Rudy Ananda. 2010. Samyutta Nikaya 6 Bagian III:Tentang Khandhw agga. Klaten: Vihara Bodhivamsa.

Marzano, R.J., et al. (1994). Assessing Student Outcomes: Performance Assessment Using the Five dimensions of Learning Model.Alexandria: Association for Supervision and Curriculum Development.

Muhammad Yaumi. 2013. Prinsip-prinsip Desain Pembelajaran. Jakarta: Kencana Prenada Media Group

Miller J.P. (2002). Cerdas di kelas sekolah kepribadian. Rangkuman modelpengembangan kepribadian dalam pendidikan berbasis kelas (disadur olehAbdul Munir Mulkhun dari Humanizing the class room oleh John. P.Miller) Yogyakarta: kreasi baru

Magdeleine \& Henk G Schmidt. Q0A7 Learning Trought assessment. Reflektion Journal http://www. eduplace.com/, diunduh 5-9 -2013

Mueller, D.J. (2006). Measuring social attitudes. New York: Teachers College,Colombia University

Marzato,R.J., et.al. (1993). Asessment student outcomes: performance assesmentusing the dimensions of learning model. Alexandria, Virginia: ASD
Mohamad Nur, (1997). '?engembangan model PBM IPA Berorientasi PKP untuk meningkatkan daya nalar siswa", Executive sunmary hasil-hasil penelitianhibah beraing perguuan tinggi, bab tV. Jakarta: Ditbinlitabmas ditjen Dikti Depdikbud.

Osborne, R. \& Withock, M. (1985). Leaning in Science: The Implications ofchildren's science. Auckland, NZ: Heinemiurn.

Popham, W.J. (1995). Classroom Assesment, what techers need to know. Boston:Allyn and Bacon

Rashid Teja SM. 1997. Sila Dan Vinaya. Jakarta: Buddhis Bodhi.

Rusidi. 2009. Undang-Undang Sistem Pendidikan Nasional. Jakarta: CV Naga Jawa Berdikari.

Slavin, E. Robert. (1997). Cooperative Learning Teori, Riset dan Praktik.Bandung: Nusa Bangsa.

Sudiyatno. 2010. Pengembangan Model Penilaian Komprehensif Unjuk Kerja Siswa pada Pembelajaran Berbasis Standar Kompetensi di SMK Tel*tologi Industri. Yogyakarta: Program Pascasarjana Universitas Negeri Yogyakarta. Disertasi tidak diterbitkan.

Suhardi, (2002). Landasan pengembangan model buku mata pelajaran Sainssekolah dasarlmadrasah ibtidayah, Yogyakarta: FP MIPA UNS

Sukardi. 2008. Evaluasi Pendidikan, Prinsip dan Operasionalnya. Jakarta: PTBumi Aksara.

Sukmadinata Nana. 20A5. Landasan Psikologi Proses Pendidikan Bandung: PT.Remaja Rosdakarya Syaodih.

Suparno. (1997). Filsafat Kontmktivis dalam pendidikan. Yogyakarta: Kanisius

Stiggins, R.J. (Summer, 1994 ) Student Centered Clossroom Assesment NewYork: Maxwell Macmilan Intemational. 
Syah Muhibbin. 2AA5. Psiklologi Pendidilmn Dengan Pendekatan Baru. Bandung: PT Remaja Rosdakarya.

Team Penterjemah. 1996. Sutta Prtaka Digha Nikaya VII. Jakarta: CV. Inti Kanari Jakarta.

Veronika, L.D. (1995). Model Mengajar Inkuiry. Jurnal Teknologi pembelajaran,teori dan penelitian. Tahun ke-3 Nomor .1-2. Oktober 1996. Bandung: Ikatan Profesi Teknologi Pendidikan PPS IKIP Bandunghttp : liwww. eduplace. com/, diunduh 5 -9-2 0 I 3 ).

Wowor Comelis. 1989. Maha Parinibbana Sutta. Jakarta: CV Lovina Indah 